\title{
Revised Stratigraphy and Mineral Resources of Balochistan Basin, Pakistan: An Update
}

\author{
Muhammad Sadiq Malkani \\ Geological Survey of Pakistan, Muzaffarabad, Azad Kashmir, Pakistan \\ Email:malkanims@yahoo.com
}

How to cite this paper: Malkani, M.S. (2020) Revised Stratigraphy and Mineral Resources of Balochistan Basin, Pakistan: An Update. Open Journal of Geology, 10, 784-828.

https://doi.org/10.4236/ojg.2020.107036

Received: May 3, 2020

Accepted: July 27, 2020

Published: July 30, 2020

Copyright (อ 2020 by author(s) and Scientific Research Publishing Inc. This work is licensed under the Creative Commons Attribution International License (CC BY 4.0).

http://creativecommons.org/licenses/by/4.0/

\section{(c) (i) Open Access}

\begin{abstract}
The Balochistan basin is located on the south western part of Balochistan Province and also Pakistan. Balochistan super basin is subdivided into northern Balochistan (Pishin basin or Kakar Kohorasan basin represented as back arc basin), central Balochistan (Chagai-Raskoh-Wazhdad Magmatic arc and Hamuns-Inter arc basin) and southern Balochistan (Makran Siahan basin) basins. Balochistan basin consists of Cretaceous to recent sediments, diverse igneous rocks and low grade metamorphics. Balochistan basin is a leading basin which consists of very significant mineral deposits especially copper and gold deposits. These mineral resources need to be developed for the development of areas, province and Pakistan. During previous half century a lot of geological work has been done in Balochistan basin. Here the revised stratigraphic set up and its mineral resources with an update are being presented.
\end{abstract}

\section{Keywords}

Revised Stratigraphy, Mineral Resources, Kakar-Khorasan, Chagai-Raskoh-Wazhdad Magmatic Arcs; Makran-Siahan Basin, Balochistan Basin, Pakistan

\section{Introduction}

All the mineral resources (except the radioactive/nuclear minerals and petroleum) are responsibility of federating units/provinces (Balochistan, North Punjab, South Punjab, Sindh, Khyber Pakhtunkhwa), Capital Islamabad, Gilgit Baltistan and Azad Kashmir while the Radioactive minerals and Petroleum (oil and gas) are under the jurisdiction of Federal government of Pakistan. Keeping in mind this, the every province should know the potential of their mineral resources, so this paper on Balochistan Basin (along with other papers on north Punjab, South Punjab, Khyber Pakhtunkhwa/KP, Balochistan and Sindh) is ar- 
ranged for the easy approach and understanding of potential of their individual mineral resources. So as well planning for the development and exploitation of their mineral resources should be implemented. At the time of independence in August 1947, Pakistan was generally perceived to be a country of low mineral potential, despite the knowledge regarding occurrences of large deposits of salt, gypsum, limestone, marble, etc. During 1950-1980, the geological community of Pakistan can be credited with several major achievements in economic geology such as discovery of major gas fields in Balochistan, uranium from foothills of Sulaiman Range in Punjab and southern KP, barite from Balochistan and KP, chromite and China clay in KP, famous emerald in KP, copper-gold and lead-zinc in Balochistan and KP. What has been found so far is much too small than what is expected to be discovered in not too distant future [1]. From independence to so far many economic geologists presented revised and updated data and papers on mineral deposits of Pakistan. From the beginning of Pakistan, many geoscientists incorporated the new discoveries in the previous records and reported the review of mineral/minerals of Pakistan or part of it. The reference [2] presented a summary of known minerals of northwestern India (now Pakis$\tan$ ) with suggestions for development and use. The references [3] [4] reported economic minerals of Pakistan. The references [5]-[8], recently [9] [10] presented a comprehensive report on mineral resources of Pakistan and [11] presented a report on mineral resources of Pakistan with basin and provinces wise which is easy for provinces to know their mineral resources, for easy approach, the mineral resources of each province was presented like Balochistan [12]-[25], Khyber Pakhtunkhwa [23]-[31], North and South Punjab [23] [34] [25], [32] [33], Sindh [23] [24] [25] [34] [35], Gilgit Baltistan [23] [24] [25] [36] [37] [38] and Azad Kashmir [23] [24] [25] [36] [37] [38]. Like this for the easy approach of mineral resources of each basin was presented like Indus Basin subdivided into Kirthar Basin [14] [21] [22] [23] [24] [25], Sulaiman Basin [14] [19] [20] [23] [24] [25], Kohat Potwar Basin [23] [24] [25] [26] [27] and Khyber-Hazara-upper Kashmir basin (part of Gondwana plate or gondwanalands, southern Earth) [23] [24] [25] [26] [27], Kohistan-Ladakh (a part of Tethys) [23] [24] [25] [26] [27], Hindukush-Karakoram (a part of Tethys and Laurasian or Asian Plate or northern Earth) [36]-[38], and Balochistan Basin [12]-[18] [23] [24] [25] which is also presented here. For easy approach of revised stratigraphic setup of each basin was presented like Indus Basin which is subdivided into Kirthar Basin [14] [20] [21] [39] [40] [41] [42] [43], Sulaiman Basin [14] [17] [19] [20] [39] [40] [41] [42] [43], Kohat-Potwar-Kotli Basin [39]-[44], and Khyber-Hazara-Neelam basin (part of Gondwana plate or Gondwana lands, southern Earth) [39] [40] [44] [45], Kohistan-Ladakh (a part of Tethys) [39] [40] [44], Hindukush-Karakoram (a part of Tethys and Laurasian or Asian Plate or northern Earth) [39] [40] [44] and Balochistan Basin including fore arc (Makran-Siahan), arc (Chagai magmatic arc) and back arc (Pishin-Kaker-Khorasan) sub basins [14] [17] [18] [39] [40] [41] [46] (part of Tethys) which is also being presented here. Recently many discoveries of gypsum and cement resources [14] [19] [20] [21] [22] [27] [28] 
[30] [32]-[37] [47] [48], fluorite [14] [15] [20] [21] [22] [49]-[54], celestite [14] [15] [19] [20] [21] [22] [53] [54] [55], coal [56]-[68], clay and ceramic [69], barite [70] [71], gold-silver associated with antimony [14] [15] [17], K-Pg boundary minerals [72], construction materials, marble and other commodities [73]-[78] are made.

The Balochistan Basin is a part of Tehys which is located on the south western part of Balochistan Province and also Pakistan. The Balochistan basin is separated from Kirthar basin in the southeast, and Sulaiman basin in the northeast by a suture zone called Western Indus Suture (WIS). The Western Indus Suture (Axial Belt) is a belt with a north south general trend located in Balochistan and Khyber Pakhtunkhwa, joined with the east west belt of Northern Indus Suture (NIS) located in the northern areas of Khyber Pakhtunkhwa, Gilgit Baltistan and Azad Kashmir. The Balochistan Basin includes the accretionary wedge complex (arc-trench gap) exposed in the south, flysch and molasses (back arc) basin in the north, and Island arc like Chagai, Raskoh and Wazhdad in the centre. The Balochistan basin consists of Cretaceous to recent sediments, metamorphic and igneous rocks. The first pioneer geological work in Balochistan Basin was done by [12]. During previous half century a lot of geological work and mineral exploration has been done in Balochistan basin. The present author along with other colleagues also carried the geological studies in Balochistan basin and other parts of the country Pakistan. Here the revised stratigraphic set up and its mineral resources of Balochistan basin with an update are being presented.

\section{Materials and Methods}

The materials belong to compiled data from previous work especially mentioned in references and also new field data collected by present author during numerous field seasons regarding the lithology, stratigraphy, mineral commodities, etc of different sub-basins of Balochistan supper basin (Figure 1) (Figure 2) (Figure 3). The methods applied here are many disciplines of purely geological methods and description.

\section{Results and Discussion}

The Balochistan supper basin is subdivided into many basin like northern Balochistan basin (Pishin basin or Kakar Khurasan basin or back arc marginal flysch and molasses basin), central Balochistan basin (Chagai-Raskoh-Wazhdad magmatic arc and Hamuns or Inter arc basins), and southern Balochistan basin (Makran Siahan basin or arc-trench gap basin) (Figure 3). Here the results and discussion are divided into two portions like the revised stratigraphy and mineral resources of different basins of Balochistan super basin, which are being presented.

\section{Revised Stratigraphy of Balochistan Basin, Pakistan: An Update}

The updated and revised stratigraphy of each basin of Balochistan super basin 
(Figure 1) is being presented here as below.

\subsection{Revised Stratigraphy of Northern Balochistan Basin (Pishin Basin or Kakar-Khorasan or Back Arc Basin)}

The present revised stratigraphy of northern Balochistan basin (Pishin or Kakar Khorasan or back arc basin) (Figure 1) is as follows.

Sharan Jogezai Group: Here proposed Sharan Jogezai Group (about 2000 meter/m thick) based on type section located along the Qila Saifullah-Sharan Jogezai road in the north of Qila Saifullah town. The Sharan Jogezai Group comprises of Cretaceous Akhtar Nika and Jabrai formations.

Akhtar Nika Formation: It is named by [79]. It consists of alternated limestone and shale. Its thickness is 1000 - $1500 \mathrm{~m}$ in the Qila Saifullah-Sharin Jogezai section. Its age is assumed Early Cretaceous on the basis of correlation with Parh group and located just below the Paleocene Nisai Group [46].

Jabrai Formation: It is named by [79]. It consists of mudstone/shale with alternation of thin marl/limestone beds. Its thickness is $500-1000 \mathrm{~m}$ exposed in the Qila Saifullah-Sharin Jogezai section. The refence [46] assumed as Late Cretaceous by law of super position and also correlation with Parh and Fort Munro groups of Sulaiman (middle Indus) basin.

Nisai Group: The reference [12] proposed the name Nisai Group (about 100 $\mathrm{m}$ thick in the type section $39 \mathrm{~B} / 1$ ) for the Nimargh limestone, Wad limestone, Wakabi limestone, Wakai limestone, Khude limestone, Kasria group, and upper parts of Jakker and Jhamburo groups. In the type section it consists of limestone, marl and shale with subordinate sandstone and conglomerate. Here the lower thin beds unit is separated from Nisai Group and included here as the proposed Sharan Jogezai Group. While the upper thick and diverse lithologies are included here as Nisai Group which is further subdivided in to three parts like lower dark limestone and pale grey shale (may be coeval to Sangiali Formation in middle Indus and Khadro Formation in lower Indus basin), the middle largely shale with some limestone, marl and sandstone (correlated to Rakhi Gaj Formation in middle Indus or Bara Formations in lower Indus) and the upper part contain thick member of limestone and sandstone with thin layer of shale and conglomerate (coeval to Dungan Limestone in middle Indus and Lakhra Limestone in lower Indus). The Nisai Group age is being assumed as Paleocene, deduced from correlation with Dungan limestone of adjoining Western Indus Suture and Sulaiman Basin [46].

Shagala Group: It was named by [46]. It includes the Murgha Faqirzai, Mina and Shagala formations.

Murgha Faqirzai Formation: It is named after the village of Murgha Faqirzai about $25 \mathrm{~km}$ north of Muslimbagh (34 M/16) [12]. It is mapped by [12] in the northern and southern Balochistan Basin and also in western Indus Suture. It comprises shale with minor sandstone and shelly limestone. The shale is pale greenish grey and calcareous. Pencil cleavage is the typical feature of this shale observed in the metamorphosed area. The sandstone is green to grey, calcareous and ripple marked. Thin shelly limestone beds are found in the base and top for 


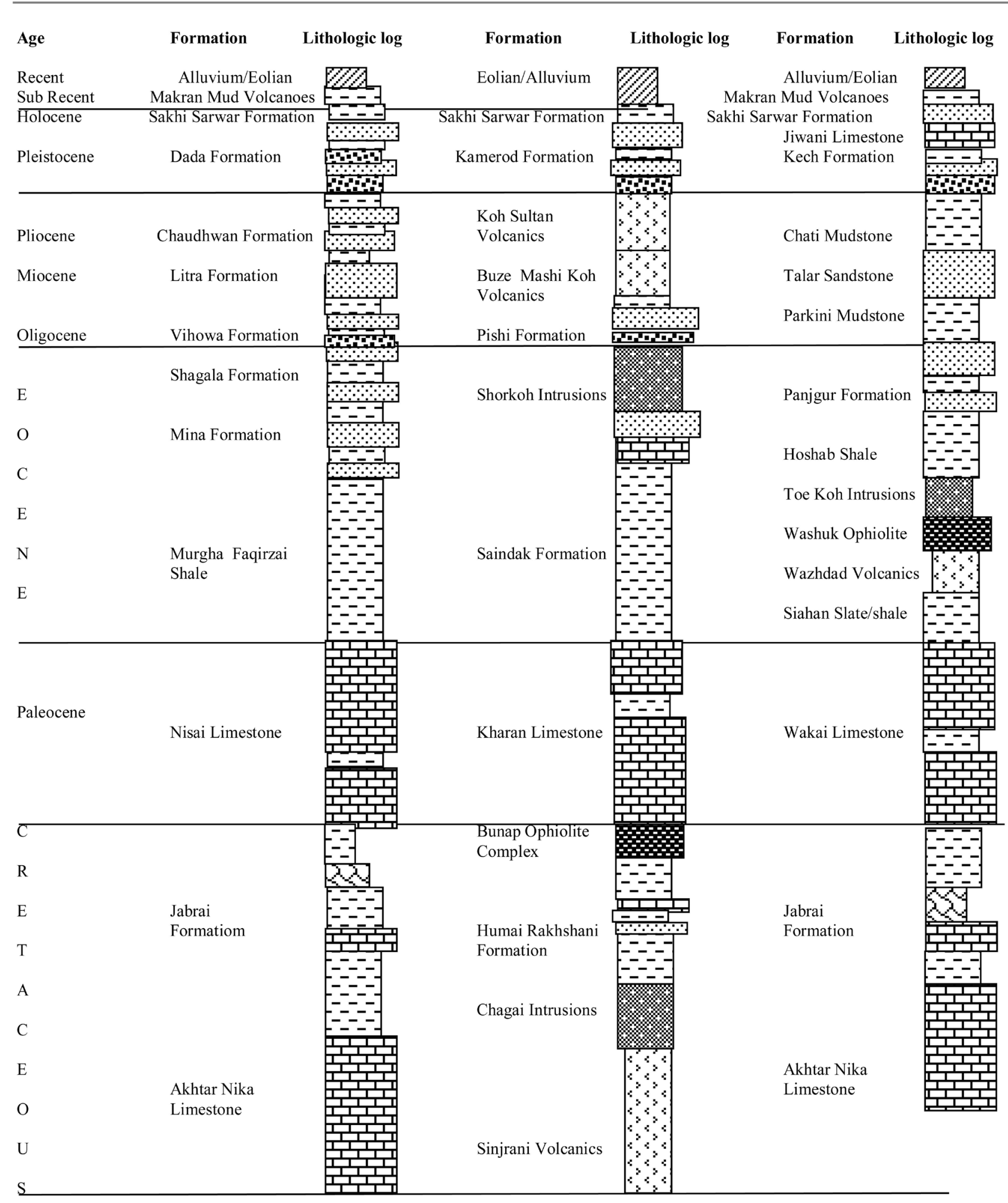

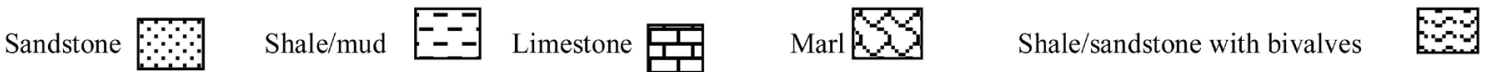 Conglomerate 6 Eolian/Alluvium 2 Volcanics/volcaniclastics $\left[\begin{array}{l}* \\ \vdots\end{array}\right]$ Intrusions $\%$ Ophiolitic complex}

Figure 1. Stratigraphic sequences of Northern, Central and Southern Balochistan basins (Pakistan). (Not on scale). 
fossil collection source. The source of this formation is mostly Hinterland and partially Indus Suture. The tentative thickness ranges from $400-1200 \mathrm{~m}$. The lower contact with the Nisai formation and upper contact with Shagala formation seems to transitional and conformable. According to stratigraphic position, its age is supposed to be Early Eocene based on correlation with Early Eocene Shaheed Ghat shale of Sulaiman basin.

Mina Formation: It is named by [46] after the Mina village on the Shagala-Zhob road which is about $30 \mathrm{Km}$ southwest of Zhob. It is coeval to Panjgur Formation in southern Balochistan basin. It consists of marine alternating green shale and sandstone which is correlated with Toi Formation of Sulaiman (middle Indus) basin. The sandstone is fine to coarse grained, gritty, thin to thick bedded, grey to greenish grey and weathers light grey and at places black desert varnish on its surface. It is about $2000 \mathrm{~m}$ thick in the northern Balochistan Basin and 1000 - $2000 \mathrm{~m}$ thick in the area between the Khwaja Amran Range and Jangal. This formation shows the marine conditions in all Balochistan basins. Its upper contact with Continental Shagala formation is disconfirmable while lower contact with Murgha Faqirzai shale is confirmable. According to stratigraphic position, its age is supposed to be Early Eocene.

Shagala Formation: It is named after the militia post of Shagala about $50 \mathrm{Km}$ southwest of Zhob (39 A/16) [12]. It consists of terrestrial sandstone and shale but at places conglomerate and limestone. The sandstone is fine to coarse grained, gritty, thin to thick bedded, grey to greenish grey, brown and weathers light grey, brown, rusty with patches of black desert varnish on its surface. In the central and eastern part of Kaker Khurasan range the sandstone is more coarsely grained and thick bedded than western part. It shows the source from the Indus Suture, however the western part may have northern and northwestern source. Some sandstone is pebbly, red and maroon. Cross bedded and ripple marks are common. The shale is maroon, red ochre type, grey, greenish grey and calcareous. The red and maroon color is dominant in the Kaker Khurasan area while grey to greenish grey shale color is dominate in the southern Balochistan basin. It is $3000 \mathrm{~m}$ thick and only exposed in the northern Balochistan Basin (Kakar-Khorasan range). This formation shows the continental (Molasse) conditions in the Kaker Khurasan range. Continental vertebrate bones of rhinoceros, crocodiles, wood fossils, etc [80] [81] [82] are also found in the Kaker Khurasan areas. Recently [80] [81] [82] found a baluchithere Pakitherium shagalai with his baby. Pakitherium shagalai-a baluchithere reported first time in Balochistan basin. Its age is middle-Late Eocene deduced from correlation with terrestrial Kingri Formation of Chamalang (=Ghazij) Group.

Vihowa Group: Vihowa group represents Chitarwata, Vihowa, Litra and Chaudhwan formations [83]. Vihowa Group is correlated with Multana formation [12] after Multana/Multanai Kili (39 E/4) west of Mina Bazar railway station. It consists of conglomerate with subordinate shale and sandstone. Its considered age is Oligocene-Pliocene. 
Sakhi Sarwar Group: It is first used by [43] after Sakhi Sarwar area of Dera Ghazi Khan. It is synonymous with Boston formation. It represents Dada (mainly conglomerate) and Sakhi Sarwar Formation named by [43] (mud and sandstone with poorly developed conglomerate, while in centre of valleys the mud is dominant) concealed at places especially in the valleys and plain areas by the Subrecent and Recent fluvial, eolian and colluvial deposits. Its considered age is Pleistocene to Holocene.

Makran Mud volcanoes: The Makran mud volcanoe is exposed north of Qila Saifullah just on the western side of road (Qila Saifullah-Sharan Jogezai road). The mud is being erupted so far. For detail pl. see in Makran Siahan basin.

Subrecent and Recent fluvial, eolian and colluvial deposits: These are also found in the valleys and vicity areas and along and in the stream channels.

\subsection{Revised Stratigraphy of Central Balochistan Basin (Chagai-Raskoh-Wazhdad Magmatic Arc and Hamuns-Inter Arc Basin)}

The Balochistan magmatic arc is located in the central Balochistan basin and consists of Chagai-Raskoh-Wazhdad magmatic arc and Hamuns-Inter arc basins. The Chagai-Raskoh magmatic arc shows Cretaceous to recent deposition (Figure 1). The revised stratigraphy of central Balochistan basin (Figure 1) is as follows.

Sinjrani Volcanic Group: It was introduced by [12] after Sinjrani tribe of Chagai. It consists of agglomerate, volcanic conglomerate, tuff and lava with subordinate shale, sandstone and limestone. It includes Basaltic-andesitic lava flows and volcaniclastics, with minor shale, sandstone, siltstone, lenticular bodies of limestone and mudstone. It is Middle to Late Cretaceous (Aptian to Santonian). This group was invaded during Late Cretaceous to Pleistocene by Chagai intrusions, represented by several phases including granite, adamellite, granodiorite, tonalite, diorite and gabbro. Its thickness is $900-1200 \mathrm{~m}$. Kuchaki Volcanic Group (equivalent of Sinjrani Volcanic Group) is named for the village of Kuchaki (34 G/8) about $63 \mathrm{~km}$ southwest of Ahmad Wal [12]. It consists of volcanic agglomerate, lava, tuff, with subordinate inpersistent limestone, tuffaceous shale and sandstone near the top of the assemblage. The upper contact with Humai Formation is generally conformable and lower contact is not exposed. Its age is Late Cretaceous.

Chagai Intrusions: It includes quartz hornblende diorite, normal diorite and biotite granite. Micropegmatitic quartz diorite is reported from Koh Naro. It is large batholiths that are invaded in Sinjrani volcanic group. The age is Late Cretaceous and later [12].

Humai Rakhshani Formation: Humai and Rakhshani formations were introduced by [12] from Koh Humai (hill of Kohi Sultan) in the eruptive zone and Rakhshani belt on eastern end of Dalbandin valley respectively for the mixed lithology which included the "Hippuritic limestone" of [84]. Conglomerate at the base, intercalations of shale, sandstone, siltstone and limestone in the middle 
and thick bedded to massive limestone at the top are reported. The formation overlies unconformably the Chagai Intrusion/Sinjrani Volcanic Group along the southern margin of the Chagai hills but in other areas has also a disconfirmable contact through the presence of basal conglomerate. It is correlated with Akhtar Nika Formation of Sharan Jogezai Group. It also includes the Juzzak Formation, lower half of Gidar Dhor Group and basal part of Pishi Group of [12]. It consists of intercalations of sandstone, shale, mudstone and limestone representing turbidite sequence, andesitic lava flows and volcaniclastics. Its age is Late Cretaceous to Early Paleocene. It is correlated wit Jabrai Formation of Sharan Jogezai Group. The age is Late Cretaceous (Campanion-Maastrichtian) [12].

Bunap Opiolite Complex: It includes the obducted ophiolite mélange which includes gabbro, diorite and serpentinite. The basic type contains pyroxene and amphibole. Its age is Latest Cretaceous or Paleocene.

Kharan Limestone: It is named by [12] after Kharan valley. It consists of medium to thick bedded foraminiferal and argillaceous limestone. Tanki sills consisting of mainly pyroxene diorite are located in the Robat limestone. Its age seems to be Paleocene. Kharan Limestone is considered as synonym with the Nisai Group (Robat and Nisai formations).

Saindak Formation; The name is derived from Saindak Fort (a large syncline) which has been designated as the type locality [12]. Its synonyms are Washap formation at Gwalishtap near the Pakistan-Iran boarder and the Amalaf formation. It consists of shale, siltstone, sandstone, marl and limestone with andesitic lava flows and volcaniclastics in the lower part. It is Early to Late Eocene. It is correlated wit Murgha Faqirzai shale of Shagala Group in northern Balochistan and Siahan shale of Siahan group in southern Balochistan.

Shorkoh Intrusions: These are dykes or sills but a few small lenticular stocks have been found in the region of Robat and Saindak. These are hypabyssal and intermediate composition. The rocks are mainly diorite. The age is Late Eocene or later [12].

Pishi Formation (=Dalbandin Formation): Pishi Formation is named here after the Pishi group which is named after the Pishi Rud lies in the Ras Koh Range while Dalbandin Formation is named after Dalbandin valley but here not well exposed. This is the reason the name Pishi Formation is preffered. These rocks are found in between Gaukoh Hamun (30 P/15) and Bunap (34 H/5). The rocks of the group are thought to be also present in the Dalbandin synclinorium named as Dalbandin Formation [12]. It consists of shale, mudstone, soft sandstone and conglomerate. The clay is white, green, ochre and brown. The succession of dominat shale unit resembles to Hoshab shale and sandstone and shale is similar to Panjgur formation of southern Balochistan. This formation is also similar to Mina and Nauroz formations. The sandstone of the Pishi area is more gritty and thick than Dalbandin and Makran flysh indicating close to source. Its age is Oligocene to Miocene.

Buze Mashi Koh Volcanics [12]: It consists of intercalations of andesitic-basaltic lava flows and volcaniclastics. It is Middle Miocene. 
Koh Sultan Volcanics [12]: It shows intercalations of dacitic-andesitic lava flows and volcaniclastics. It is Late Pliocene to Pleistocene.

Kamerod Formation: It is derived from Kamerod on the northern margin of the Siahan range $(31 \mathrm{M} / 10)$ [12]. The lithology and description is same as Kech Formation. Its age considered is Pleistocene.

Subrecent and Recent deposits: These deposits are represented by unconsolidated gravel, sand, silt and clay, and Eolian sands in the Chagai-Dalbandin trough.

\section{Revised Stratigraphy of Wazhdad Magmatic Arc}

The Wazhdad magmatic arc is a northernmost part of Siahan Range and located just south of Hamun Mashkel. This is the reason its stratigraphy is reported under the southern Balochistan Basin (Figure 1). Its southern boarder with Siahan-Makran basin is being marked at the thrusted ophiolitic line on the southern base or foot of Toe Koh (just west of Washuk town; $35 \mathrm{~A} / 10$ ) (Figure 2), Wazhdad Range (35 A/6) (Figure 2) and Zurati Range (31 M/11) (Figure 2). Here the Zurati, Wazhdad and Toe Koh rocks are named as Wazhdad magmatic arc and included in the Balochistan magmatic arc due to lithology and Washuk ophiolitic thrust line. The Makran and Siahan basin is located just south of Washuk Ophiolite thrust line. The revised stratigraphy of Wazhdad Magmatic Arc represents Eocene Siahan Group (correlated to lower part of Murgha Faqirzai shale) includes Siahan slates and shale, Wazhdad volcaniclastic group (synonym Zurati formation), Washuk Ophiolite complex and Toe Koh (Washuk) Intrusion, Late Eocene-Oligocene Makran Group (Shagala Group of north Balochis$\tan$ ) consists of Hoshab shale (=upper part of Murgha Faqirzai Shale of north Balochistan), and Panjgur sandstone and shale (=Mina sandstone and green shale of northern Balochistan), and Pleistocene-Holocene Kamerod Formation and Subrecent to Recent alluvial, colluvial and eolian deposits. The detail is provided in Makran and Siahan basin.

\section{Stratigraphy of Hamuns (inter arc) basins}

Hamuns basins are Inter arc basins found in the central Balochistan Basin which represents exposed eolian sand dunes covering the fluvial Pleistocene Kamerod formation (conglomerate, sandstone and clays). The older rocks may be like Chagai-Raskoh magmatic arc and Wazhdad magmatic arc.

\subsection{Revised Stratigraphy of Southern Balochistan (Makran Siahan) Basin}

Recently many workers carried the geological investigation in Malkan and Siahan ranges of southern Balochistan [85]-[97] and other areas. The revised stratigraphy of southern Balochistan basin (Figure 1) including the Wazhdad magmatic arc are shown as below.

Sharan Jogezai Group: The Cretaceous Sharan Jogezai Group consists of Akhtar Nika and Jabrai formations representing Parh like porcellaneous limestone, marl and shale. It is exposed near Mand [12] which is located near the Iran-Pakistan boarder. 
Nisai Group: The Paleocene Nisai Group consists of Ispikan conglomerate and Wakai limestone and shale. It is exposed as lense shaped distributed as rare exposures.

Ispikan conglomerate: It is named after the village of Ispikan about 12 miles northeast of Mand (31 J/4; [12]). Conglomerate consists of pebbles of quartz, granite, andesite, and other igneous rocks. Matrix of conglomerate is chloritic (green). Its lower contact with the thin bedded marl assigned to Parh series seems to be unconformable. Its upper contact is not clear but some remnants of Wakai limestone are found at the eastern end of the hill near Ispikan which show contact with Wakai formation. Age of Ispikan conglomerate is Paleocene determined by stratigraphic position between the Cretaceous and Eocene rocks and some diagnostic fossils [12].

Wakai Limestone: It is named after Koh-i-Wakai in the valley of Tagrana Kaur $(31 \mathrm{~J} / 11 ;[12])$. It consists of limestone, marl and shale. The age of formation is interpreted as Paleocene. Its synonym is Nisai Limestone. The formation is important for petroleum prospecting and source, if it has large subsurface thickness, extension and suitable conditions.

Siahan Group: It is named by the [14]. It represents Siahan slates and shales, Wazhdad volcaniclastics, Washuk ophiolite complex and Washuk Intrusion.

Siahan Formation: It is named after the Siahan Ranges (31 M/8; [12]). It comprises slates and shale with siltstone, sandstone and quartzite. The lower contact is with Wakai limestone and the upper contact is with the Wazhdad volcaniclastic group which is conformable. According to [12] megafossils are rare in the shale and can not be thoroughly tested for microforaminifers, however some thin limestone beds yielded fossils which show Eocene age. According to [12] and stratigraphic position the age is Early Eocene.

Wazhdad Volcaniclastic Group: It is named after the Wazhdad Mountain (35 A/6) by [96] for Wazhdad volcaniclastic group. This is synonym and coeaval to Zurati Formation. Zurati formation is named after the Zurati Koh and Tank e Zurati $31 \mathrm{M} / 11$ [92]. The Wazhdad Range is located just west of Washuk and east of Palantak. These rocks are exposed in the Wazhdad Mountain (35 A/6) and may be extending upto Toe Koh 35 A/10 (Figure 2) in the east and Zurati Tank $31 \mathrm{M} / 11$ in the west (Figure 2). It consists of tuff, agglomerate, tuff breccias, tuffaceous sandstone and shale. These rocks are dark green colour and weather in to dark grey to black colour, hard and resistant, forming high peaks. The estimated thickness of this formation is 1200 to $1500 \mathrm{~m}$ in the Wazhdad Range, the actual measurement is also difficult due to intense faultings and foldings. Their lower contact with the Siahan shale and upper contact with Hoshab shale seems to be transitional. According to law of superposition the age of Wazhdad volcaniclastic group may be early to Late Eocene.

Washuk Ophiolite Complex: It is named by the [96]. This ophiolite (part of complete sequence) is exposed in the thrusted plane of Wazhdad mountain range. The thrust line is located on the southern side of Wazhdad mountain 
range at Mazargati (35 A/6), Jhal Kaur (35 A/7), and Toekoh (35 A/10) and also in Zurati (31 M/11) areas (Figure 2). The observed rocks are granite, peridotite, bronze dunite, asbestos, (serpentine), soapstone (talc), and chromite. Its exposures are small, however in the southern vicinity, there is a wide alluvium cover which may yield more ophiolitic rocks in subsurface. The contact with the Wazhdad volcaniclastics is faulted. Some phylite/schist is observed near the contact zone. The age may be Eocene or late Eocene.

Toe Koh Intrusions (=Washuk Intrusion): Toe Koh intrusion is named after the host Toe Koh just west of Washuk town. The Washuk Intrusion is its synonym. Tow Koh Intrusions are exposed on the southern foot mountain or base of Toe Koh (Washuk-Palatank) mountain Range (Figure 2). It mostly consists of acidic rocks like granite. The possible age is Eocene or late Eocene.

Makran Group: It is represented by Late Eocene to Oligocene Hoshab and Panjgur formations.

Hoshab Formation: It is named after the village of Hoshab in the Kech valley (31 N/16; [12]). The reference [12] correlated it with the upper part of Murgha Faqirzai shale of north Zhob district. It comprises shale with minor siltstone and sandstone. The lower contact with the Wazhdad formation and upper contact with the Panjgur formation which are conformable. Further [12] correlated the Hoshab shale with the upper part of Murgha Faqirzai shale of northern Balochistan basin

\begin{tabular}{|c|c|c|c|c|c|}
\hline $\begin{array}{l}63^{\circ} 30^{\prime} \mathrm{E} \\
27^{\circ} 45^{\prime} \mathrm{N}\end{array}$ & & 29 & $\begin{array}{l}36 \\
40\end{array}$ & 39 & 24 \\
\hline 42 & $26^{27}$ & 34 & $\begin{array}{ll} & \\
& \\
& \\
& \end{array}$ & \begin{tabular}{cccccc}
9 & 8 & 7 & 5 & 2 & 1 \\
10 & 6 & 3 & 43 \\
11 & \multicolumn{3}{c}{31} & & \\
18 & 16 & 19 & 14 & 12 & 15 \\
17 & \multicolumn{3}{c}{13} & \\
20 & & & &
\end{tabular} & \\
\hline 38 & $33 \quad 32$ & 30 & & & $\begin{array}{r}65^{\circ} 00^{\prime} \mathrm{E} \\
27^{\circ} 00^{\prime} \mathrm{N}\end{array}$ \\
\hline
\end{tabular}

Figure 2. Mineral localities of Makran and Siahan basin (Southern Balochistan Basin). The stibnite-gold localities are 1-Jauder, 2-Mahmoodi, 3-Sor Jor Jauder, 4-Damagi Nagindap, 5-Hashani, 6-Damagi Hashani, 7-Ahmadap, 8-Panir Body East, 9-Panir Body West, 10-Kasig (northern slope), 11-Musa Kaur, 12-Kuchaki North, 13-Kuchaki South, 14-Gokumb, 15-Siagari, 16-Surmagi North, 17-Surmagi South, 18-Huspi, 19-Hurain, 20-Kulo, 21-Gazin, 22-Aj Geiji, 23-Siminj, 24-Lidi, 25-Miani, 26-Machi Koh, 27-Mir Baig Raidgi, 28-Safed Gilanchi, 29-Palantak, and 30-Saghar. Major quartz vein locality 31-Siagari Shand. Mercury-silver quartz vein networks locality 32-Eastern Waro. Mercury-silver ferruginous zone locality 33-Western Waro. Meteorite (room sized Hematitic body with outer green colour) 34-Soro and Phudkush. Pyrite localities 35-Sorap, 36-Wazhdad, and 37-Durgi. Coal and carbonaceous shale and sandstone locality 38-Ahurag. Toe Koh Intrusion (Washuk Intrusion) mainly granitic intrusion locality 39-Toe Koh (west of Washuk town). Washuk Ophiolite Complex (east-west trending thrust fault line with negligible showing of soapstone, malachite, asbestos and chromite) localities 40-Mazargati and 41-Johl. Wazhdad Volcaniclastics (synonym Zurati Volcaniclastics) 36-Wazhdad, and 42-Tank Zurati. Petroliferous and sulphurous water spring locality 43-Sor Jor Jauder. 
and Siahan shale of Wazhdad magmatic arc. According to stratigraphic position, its age is supposed to be late Eocene.

Panjgur Formation: It is named after the Panjgur town (35 B/1; [12]). It consists of alternated sandstone and shale. Sandstone is light green to light grey to grey, fine to medium grained, thin to thick bedded, hard and calcareous. It is correlated with the Mina Formation of north Balochistan basin (Kakar Khorasan basin). Panjgur formation is devoid of fossils in the Panjgur area, however on the west of Panjgur near Iran Boarder, this formation has yielded Oligocene age diagnostic foraminifers [12]. Further the stratigraphic position tells Early to Late Oligocene. The undersurface sedimentary structure commonly observed are groove marks, and load casts, and rarely observed are flute casts, upper surface sedimentary structures are ripple beddings. A general paleocurrent direction of Eocene-Oligocene strata of northwestern part of Makran basin was northwest to southeast, deduced from the vector sedimentary structures such as flute casts, and scalar sedimentary structures such as ripple and groove marks. However the source of the northeastern part of Makran basin seems to be both from northwestern and also from east/Indus Suture due to its close vicinity.

Talar Group: It is named by Malkani [14]. It represents marine Parkini mudstone, Talar sandstone and Chatti mudstone. The Hinglaj series of Vredenburg is considered in this group. Talar Group is well exposed in the South Makran.

Parkini Formation: It is named after the Parkini Kaur, a tributary of the Hingol River (35 G/6) [12]. It consists of mostly poorly bedded mudstone with minor intercalations of siltstone or fine sandstone. The lower contact with the Panjgur formation is abrupt and gradational and upper contact with the Talar formation is transitional. Large fossils are rare while Miocene microforams are prolifically abundant and can be obtained relatively easily from the mudstone, most of which disintegrates readily in warm water. According to microforms and stratigraphic position its age is Early Miocene.

Talar Formation: It is named after the Talar gorge (31 K/10) [12]. It is considered equilent to Hinglaj group of [12]. It consists of sandstone, shale, mudstone and shelly limestone. Its lower contact with Parkini and Chatti formations is transitional but at places sharp. The fossils like gastropods (Mollusks) and lamellibranches are common. The microforms are Miocene age diagnostic [12]. The age of the formation is Late Miocene to Early Pliocene.

Chatti Formation: It is after the locality of Chatti $(31 \mathrm{~K} / 3)$ about 17 miles north west of Gawader [12]. It is a part of Makran series paleontologically defined by [84]. It consists of mostly mudstone which is interbedded with siltstone or fine grained sandstone and marl. The Ormara is the synonym of Chatti because Ormara is mapped in the eastern part of southern Makran coastal areas where Chatti formation is not mapped and distinction between Ormara and Chatti mudstone is also difficult in the western part also [12]. Its age may be Pliocene.

Kech Formation: It is named by [12] after the Kech valley near Gish Kaur 
(Map 9; 31N/8) and Kech Valley generally existed from Hoshab area to Turbat. It is also correlated with Kamerod/ partly Ormara formation. It consists of conglomerate, mudstone and sandstone facies. It also has upper angular contact with Subrecent to Recent surficial deposits. The age of the formation is Pleistocene.

Jiwani Formation: It is named after the coastal village of Jiwani $(31 \mathrm{G} / 12)$, where it is best exposed. It is synonymous with the "Sub-Recent shelly limestone" and "littoral concrete" [98]. The formation is restricted to the South Makran division of the arenaceous zone and has a thickness upto 100 feet in the type area of Jiwani headland [12]. The formation is composed mainly of shelly limestone, sandstone, and conglomerate. The lower contact with Ormara formation is gradational and placed at the base of lower persistent bed of shelly conglomerate, and at places angular unconformable with Ormara, Parkini and Chatti formations. Its upper contact with the recent deposits or extrusive mud may be angular. The age may be Late Pleistocene to Subrecent [12].

Makran Mudvolcanoes: These are common in coastal areas of Makran but also found in the Pishin Zhob basin particularly near the Qilla Saif Ullah area [12]. It consists of solidified silty and gritty muds. It is soft and friable. In general the mud appears in two forms like cones and ridges. The cones formed by one or more ventral vents. It involves series of eruption and cone is formed from the drying of muds. The ridge type of mud accumulation seems to have no connection with ventral vents or discrete points of eruption but appear as high, broad hill with steep sides and long and parallel with the regional structures. Rutile and methane gas is also present in these volcanoes. Its age may be Sub Recent to Recent.

Subrecent and Recent deposits: These are represented by Terrace gravel deposits, Fan gravel deposits, sand, silt and clay deposits (cultivated and noncultivated lands), Hamun deposits like eolian Sand dunes (Seif/longitudinal and Barchann), and present channel deposits.

\section{Revised Stratigraphy of Makran offshore}

The offshore areas are significant for petroleum exploration. The Makran offshore areas located in the west of Western Indus Suture line and show the Makran-Siahan (southern Balochistan) basin stratigraphy and further the trench is also located in the near offshore area. The Indus offshore area is located in the east of Indus Suture line and is significant for petroleum exploration because it shows the Kirthar (lower Indus) basin petroleum productive stratigraphy.

Depositional Environments, Geological History and Geoevents of Makran-Siahan basin

Makran-Siahan (arc-trench gap) basin shows structural features like complex (close) folds, imbricate (reverse) faults, strike slip faults, cuesta and hog back topography. General axes of folds and imbricate/reverse faults are E-W and NE-SW. The dips of synclines and anticlines of the Tertiary strata are greater than $50^{\circ}$ in the north and less than $50^{\circ}$ in the south. The major anticlines are located in the high area and synclines in the low area. The trends of the strike slip faults are mostly oblique to the bedding. The Pleistocene strata show dips less 
than $30^{\circ}$ which form open folds in and around the valleys. During Late Cretaceous Indo-Pakistan plate started journey, and connected with Balochistan basin via western Indus Suture. Due to northward movements of Indo-Pakistan subcontinent resulted as Chaman-Nal-Ornach transform fault boundary just close to belt of western Indus Suture. Ornach-Nal-Chaman transform fault shows the left lateral fault movement in the western boarder of Indo-Pakistan continental plate and eastern boarder of Balochistan basin but its some parts like Noshki-Chaman portion is sandwiched in the northern Balochistan (Pishin/Kakar Khorasan basin) due to dragging effect while here the western Indus Suture is located on the eastern side at western Quetta (Shaikh Wasil)-Kuchlak-Muslimbagh-Qila Saifullah-Zhob line. Convergence of Indo-Pakistan plate with Asian plate affected the Arabian plate. In this way Arabian plate convergence and subduction in the Tethys came into existence and resulted in the form of Bazman volcanics in Iran, and Chagai, Raskoh and Wazhdad magmatic arcs or volcanics in Pakistan termed as Balochistan Island arc. At present the convergence trench is located in off shore areas. The Kaker-Khurasan (back arc) basin show early flysch condition of Murgha Faqirzai shale and later molasse condition of Shagal (=Shaigalu) formation with source in the north east from Indus Suture. Makran and Siahan basin are located in the arc-trench gap, which represents accretionary wedge complex. The Cretaceous porcellaneous marl and limestone (Parh like) of Sharan Jogezai Group exposed in the Mand area [12]. Paleocene Ispikan conglomerate shows unstable marine conditions and Wakai limestone shows the reef marine reef condition. The Early Eocene Siahan slates and shale and Wazhdad volcaniclastics, turbidite sandstone and shale facies deposited under marine conditions and slate and quartzite are results of metamorphism by geodynamics and tectonics. During Late Eocene to Oligocene the sandstone, shale and siltstones sequence of Hoshab and Panjgur formations of Makran Group are deposited in marine environment. The Late Eocene to Oligocene Washuk ophiolitic rocks are thrusted at the southern base of Toe Koh Washuk-Wazhdad-Zurati ranges (Wazhdad magmatic arc). Wazhdad magmatic arc is the third magmatic arc after Chagai and Raskoh in Balochistan and increase its spatial extension. Washuk ophiolites have also faulted contact with Wazhdad volcaniclastics of Early Eocene age and late Eocene Hoshab shale and Oligecene Panjgur formations show the unstable obduction condition. During Miocene and Pliocene the Talar Group was deposited in southern Makran with eastern source from western Indus suture, while there is no deposition during this period in northern Makran and Siahan ranges which show the uplift by tectonism and convergence of Arabian plate and further uplifting and obduction of Washuk opiolite thrust belt which is generally trended east west. This uplift is confirmed by the angular unconformity between Pleistocene Kamerod formation and older formations. During Pleistocene the Kech/Kamerod/Gawader formation are deposited which show the lithology as mudstone, sandstone, and conglomerate of fluvial and lacustrine origin. Con- 
glomerate deposited near the source, while the mudstone far from the source and sandstone in transitional stage. Existence of gypsum gives clue to the lacustrine evaporation or lagoonal environments. The Pleistocene Jiwani shelly limestones show the coastal environments. After the deposition of Kech/Kamerod formation, further uplift took place and this evidence is confirmed by the angular unconformity in between the Kech/Kamerod formation and surficial subrecent and recent deposits. Subrecent and Recent deposits show the continental fluviatile, eolian seif and barchan sand dunes (wind action), and hamun (lacustrine playa) deposits. Active mud volcanoes are also common due to overburden pressure and temperature in old muddy formations.

As a whole four main geoevents of subduction of Arabian plate in Tethys are interpreted. First event of tectonic activity occurred at the end of Paleocene which changes the calcareous limy conditions (Wakai limestone) into flysch shale and sandstone conditions (Siahan/Hoshab shale, Wazhdad/Panjgur formation). This episode is also responsible for deposition of Sihan shale and Wazhdad volcaniciclastics. The second event of tectonic activity happened at the end of Eocene or Oligocene which resulted as the obduction of Washuk ophiolite. By this phase the Siahan and northern Makran were uplifted. This is confirmed by the non deposition during Miocene and Pliocene period. Third event happened at the Late Pliocene or Early Pleistocene and areas uplifted which is confirmed by the deposition of conglomerate in Pleistocene deposits and also angular unconformity between the older strata (Eocene/Oligocene) and Pleistocene Kech/Kamerod formation. This phase is responsible for the foldings and faultings of older strata. Fourth event of tectonic orogeny occurred at the end of Pleistocene or start of Holocene which is confirmed by the angular unconformity between Kech/Kamerod (Pleistocene) and Holocene surficial deposits. This phase is responsible for the open folding of Miocene-Pleistocene strata and intense (complex) foldings, and imbricate and strike slip faultings of Oligocene, Eocene and older strata. In some places the Subrecent and Recent surficial deposits show the fault alignments and give some dip and other features show the rising and continuous movement of convergence plates.

\section{Mineral Potential of Balochistan Basin, Pakistan: An Update}

The reference [99] reported the production from Balochistan Province during 2007-08, 36,583 tons (t) copper, $245 \mathrm{t}$ antimony, 49,268 t barite, $331 \mathrm{t}$ basalt, $33,815 \mathrm{t}$ chromite, $25 \mathrm{t}$ clay, 2,325,220 t coal, $291 \mathrm{t}$ granite, $259 \mathrm{t}$ rhyolite, $134 \mathrm{t}$ diorite, $183 \mathrm{t}$ gabbro, $2431 \mathrm{t}$ serpentinite, $98 \mathrm{t}$ gneiss, $323 \mathrm{t}$ quartzite, $360 \mathrm{t}$ sulphur, $176 \mathrm{t}$ dolomite, $424 \mathrm{t}$ fluorite, $75 \mathrm{t}$ galena, 15,808 $\mathrm{t}$ iron ore, 727,951 t limestone, 70,740 t marble (onyx), 267,312 t marble (ordinary), $790 \mathrm{t}$ magnesite, $1385 \mathrm{t}$ manganese, $5060 \mathrm{t}$ pumice and 1,306,764 t shale. Mineral resources of Balochistan Province have many large proven reserves which are are being described here. 


\subsection{Mineral Resources of Northern Balochistan Basin (Pishin Basin or Kakar Khorasan Basin)}

Some economic minerals/commodities like antimony, ochre, saline springs, and mud flows with methane-nitrogen gas are found (Figure 3). Antimony deposit like the stibnite veins are hosted in Khojak group of Qila Abdullah which is 24 $\mathrm{km}$ NE of Qila Abdullah town, and smaller deposits in the Qila Viala area $40 \mathrm{~km}$ east of Qila Abdullah [5] [12] [13] [100] [101]. Ochre deposits are found in the Shaigalu sandstone of Kaker Khurasan area [9]. Many Saline springs are found in the Qila Saifullah area especially in the Nisai formation. Salt springs running and dry are reported from the red shale at the base of Nisai limestone and so far active mud volcano in the Spara Manda and its vicinity areas of Qila Saif Ullah district (39 B/5.9) [14].

\subsection{Mineral Resources of Central Balochistan Basin (Chagai-Raskoh-Wazhdad Magmatic Arc and Hamun Mashkel Basin)}

\section{Mineral Resources of Chagai Magmatic Arc}

The Chagai arc is economically most important mountain belts of Pakistan.

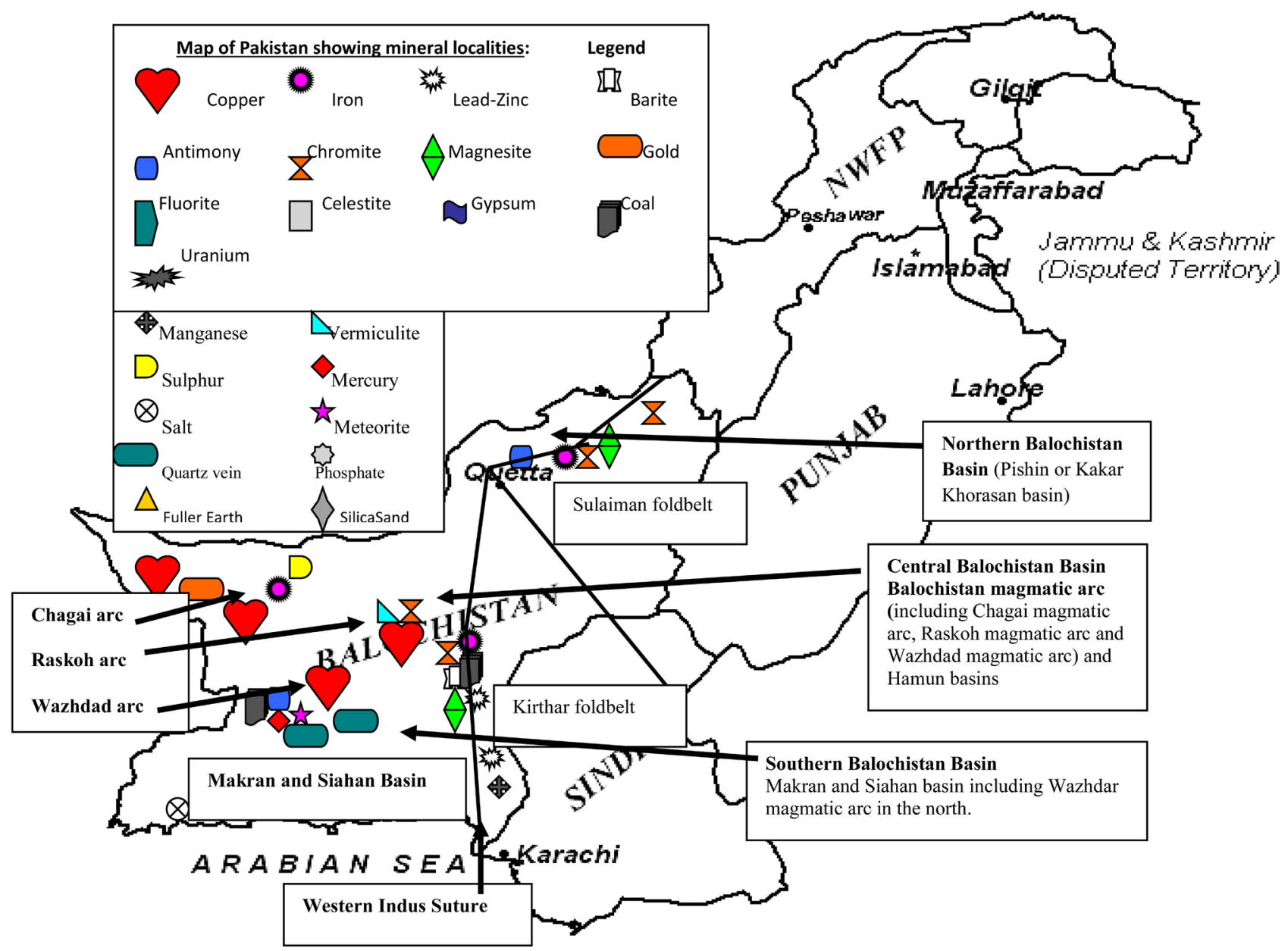

Figure 3. Map of Pakistan showing mineral localities in northern, central and southern Balochistan Basins (a Tethyan block), Pakistan. 
Many important minerals (Figure 3) including porphyry ( $\mathrm{Cu}-\mathrm{Mo}-\mathrm{Au}$ ), manto and vein type copper, stratiform and skarn type iron, volcanogenic gold-silver and sulphur, Kuroko type lead-zinc-silver-copper are intimately associated with the magmatic rocks of this arc [102] [103]. The tholiitic and calc-alkaline magmatism in oceanic island arc was reported by [102] [103] while before this it was considered as Andean type (continental) calc-alkaline magmatic belt.

Copper: The copper deposits and showings occur extensively at several localities in the Chagai magmatic arc [12] [102]-[109]. Dasht Kain copper deposit is $35 \mathrm{~km}$ NW of Chagai village $\left(29^{\circ} 33^{\prime} \mathrm{N} ; 64^{\circ} 29^{\prime} \mathrm{E}\right)$ is porphyry type copper prospect associated with two tonalite porphyry stocks. The stocks are intruded into a diorite cupola which is a part of a large batholith comprised of quartz monzonite and diorite. The batholith has intruded the Cretaceous Sinjrani volcanic group. The host rock tonalite porphyry is centered by potassium silicate alteration and followed outwardly by quartz sericite and porphyritic alterations. There is a moderate to weak $\mathrm{K}$ zone and the hypogene mineralization has developed in two phases, the first phase produced pyrite, chalcopyrite, enargite and pyrrhotite and the second one introduced magnetite, molybdenite and chalcopyrite [103]). Three bore holes have been drilled in western stock. Average copper values in quartz sericite zone vary from $0.1 \%-0.17 \%$ and in the potassium silicate zone from $0.25 \%$ to $0.54 \%$. The breccia pipe zone in the eastern stock contains surface values upto $4.5 \%$ copper but not drilled [8]. Talaruk copper deposit is $64 \mathrm{~km} \mathrm{NW}$ of Saindak in Chagai District. It is a massive Kuroko type deposit and mineralization is of submarine exhalative origin. The copper ore occurs in two zones, one in rhyolite intrusives in which chalcocite is the main copper mineral and the other in volcanic breccia associated with gypsum, with malachite as the main copper mineral. Six bore holes were drilled at this deposits and its copper content has been about $0.65 \%$ [110]. Saindak copper deposit is located about $9.4 \mathrm{~km} \mathrm{SE}$ of Fort Saindak $\left(29^{\circ} 18^{\prime} \mathrm{N}\right.$; $\left.61^{\circ} 33^{\prime} \mathrm{E}\right)$ in Chagai district. The ore is hydrothermally altered and the mineralized zone is known as Saindak alteration zone [111]. It is developed in siltstone, sandstone, and tuff of Amalaf Formation. The mineralization is related two small patterns centered on three porphyry stocks of Mid-Miocene age and consequently there are three main ore bodies, the North, South and East ore bodies. The north ore body is developed along vein zones though oxide mineralization is also present in patches. Nineteen bore holes were drilled on this body and $19 \mathrm{mt}$ of ore averaging $0.498 \%$ copper (cut off grade $0.3 \%$ ) has been proved. The south ore body lies $2 \mathrm{~km}$ south of north ore body. Here the oxide zone is developed in patches. The ore is developed within a few meter of the surface and has been proved to a depth of $328 \mathrm{~m} .27$ holes were drilled and reserves of $54 \mathrm{mt}$ of ore averaging $0.488 \%$ (cut off grade $0.3 \%$ ) including $27 \mathrm{mt}$ of $0.64 \%$ copper at cut off grade of $0.4 \%$ have been proved. Significant gold and molybdenum values are associated with this ore body. The east ore body is $1 \mathrm{~km}$ SE of the south ore body. A lean, patchy copper oxides zone with $0.4 \%-0.5 \%$ 
copper is developed over the ore body. In this area 37 bore holes have established indicating reserves of $264 \mathrm{mt}$ averaging $0.388 \%$ copper at cut off grade $0.3 \%$. The total reserves at Saidak comprised $412 \mathrm{mt}$ of ore containing average $0.38 \%$ copper and $0.3228 \mathrm{gm} / \mathrm{to}$ of gold. At Saindak an open cast mine with infrastructure, crushing plant, concentrators and smelter has been developed and trial production of blister copper has been done. It is planned to produce annually 15,800 tons of copper, 1.47 tons of gold and 2.76 tons of silver [112]. Other porphyry copper deposits in Chagai district were explored and evaluated by BHP. Their results suggest that the western part of the district has great potential for development of porphyry copper deposits. Based on the results of 80 test holes, it is estimated that this region has reserves of $550 \mathrm{mt}$ [113] of averaging $0.4 \%$ to $0.6 \%$ copper and 0.2 to $0.5 \mathrm{gm} /$ ton of gold. According to BHP besides Rekodiq, Buzzi Mashi and western Ware Chah, other localities such as Parrah Koh, Borghar Koh, Koh Dalil, Koh Sultan and Ting Daragaun look promising and merit detailed exploration. Tethyan Copper Company has recently drilled 30 holes at Rekodiq (Koh Dalil) and has encountered a chalcocite blanket and hypogene zone. In this zone reserves of $70 \mathrm{mt}$ of ore with $0.85 \%$ copper are indicated. Chagai areas like Talaruk, Saindak, Rekodiq, Max. G. White, Koh-e-Dalil (Sam Koh), Mashki Chah, Darband Chah, Amuri, Yakmach, Kangord, Galtori, Omi, Ziarat Pir Sultan, Kabul Koh, Missi, Humai, Dasht Kain, Koh-i-Marani, Pakus nala, Nok Chah, Dalbandin, Amir Chah, Ziarat Malik Karkam, Bazgawanan, Kundi Balochap, Bandegan, Robat, Buzzi Mashi, Western War Chah porphyries, Parrah Koh, Bor Ghar Koh, Malaik Koh, Ting Daragun, Machi and Kirtaka [8] [12] [104] seem to be significant.

Gold-Silver: The production of copper along with gold will be started soon from Saindak porphyry copper deposits. GSP has discovered a number of porphyry copper deposits with gold and silver mineralization [114]. Telethermal vein type and skarn deposits are also reported. Broken Hill Propriety (BHP) of Australia in collaboration with BDA has discovered world class gold deposits. Lake Resources (Australia) also explored copper and associated gold deposits and their alteration zones [8].

Iron ore: Balochistan Basin show iron from Saindak, Mashki Chah, Durban Chah, Amir Chah, Chilghazi, Gorband, Kasanen Chapar, Kundi Baluchap, Pachin Koh, Chigendik, Bandegan and Nok Chah areas [5] [12] [105] [106] [115] [116]. Pachin Koh-Chigendik iron deposits are located $88 \mathrm{~km}$ and Chigendik $40 \mathrm{~km} \mathrm{NW}$ of Nokundi town. It is comprised of magnetite and hematite. It is volcanogenic and occurs as intercalations with andesites of Sinjrani volcanics. The ore contains $\mathrm{Fe}_{2} \mathrm{O}_{3} 767 \%-82 \%, \mathrm{SiO}_{2} 9 \%-22 \%, \mathrm{Al}_{2} \mathrm{O}_{3} 1.4 \%-$ $4.4 \%$ and $\mathrm{CaO} 1.2 \%-2.2 \%$ [8] [117]. There are 27 small magnetite-hematite bodies at this area. At Pachin Koh 62 holes, where as 29 holes in Chigendik drilled. The estimated ore reserves of Pachin Koh are $45 \mathrm{mt}$ and of Chigendik is $5 \mathrm{mt}$ of which $30 \mathrm{mt}$ are proved. The geological and geophysical investigations show that the deposit may be increased upto $100 \mathrm{mt}$. Steel mills process 
this ore with $46 \%$ substitute of the imported ore. The reference [118] has suggested the ore is suitable for direct reduction plus electric arc furnace process combination. This process can produce steel billets at about 30\% lower cast. Chilghazi iron deposits are located $52 \mathrm{~km} \mathrm{NW}$ of Dalbandin town. The area is underlain by Cretaceous Sinjrani volcanics, which are intruded by small bodies of diorite, quartz monzonite and granodiorite. The deposit sis found in Sinjrani which forms asymmetrical gently dipping anticline. The iron ore is comprised of massive magnetite and layers of disseminated magnetite. The ore occurs at three horizons. The upper one near the top contains main deposits. The other two are 166 and $500 \mathrm{~m}$ below the first one. The lower ore bodies are largely comprised of magnetite disseminations in volcanic rocks and are lean in their iron content $(10 \%-12 \%)$. The deposit has been drilled and indicates the main ore body contains iron $32 \%-52 \%$ (average $45 \%$ ), copper $0.1 \%$ $1.96 \%$ (in one hole upto $7 \%$ ), phosphorous upto $0.1 \%$. Some portion of the ore body contains upto $1 \mathrm{oz} /$ ton of gold [13] [119]. It has high grade ore with 3.36 $\mathrm{mt}$ ( 2.46 proven and 0.90 probable). The low grade reserves with $25 \%-30 \%$ iron are estimated $20 \mathrm{mt}$ [120].

Tungston: The tungsten ore has been recorded by [121] [122] from Amalaf $\left(29^{\circ} 18^{\prime} \mathrm{N} ; 61^{\circ} 37^{\prime} \mathrm{E}\right)$ in Chagai district. The ore is found in pyroclastic rocks of Saindak formation intruded by quartz porphyry. The ore minerals are sheelite and tungstite associated with molybdenum and tin minerals. The mineralization is attributed to xenothermal alterations in the host rock.

Sulphur: Sulphur deposit is located in the Koh-i-Sultan volcano. Massive layers and lenses are interbedded with the Pleistocene volcanic ash. The ore contains $50 \%$ sulphur and reserves of 738,000 tons [123]. Potential source of sulphur are Kohi-Dimak dome, desulphurization plants in the coalfields, sour gas (gas containing hydrogen sulphide in Natural gas, anhydrite and gypsum.

Marble: The marble ([124] [125] and various types of limestones and igneous rocks, mainly granite are found from Chagai area can be used for buildings, construction and Decorative stones.

Gemstones: The chalcopyrite, malachite, azurite, chert, jasper, garnet, epidote, tourmaline, quartz and minerals of hornblend and pyroxene, etc. are common gemstones found in the Chagai magmatic arc of Balochistan basin.

Others: Lead-zinc [126] is reported from Saindak, Koh Marani, Dirang Kalat, Makki Chah (4 km SE of Talaruk) and Ziarat Balanosh (100 km NE of Dalbandin). Manganese from Nushki (9 km north of town), Barite from Chagai area (Koh Sultan), Barite from Chagai area (Koh Sultan), tourmaline from many sites from Chagai area, Zinc from Makki Chah area is reported [8]. The reference [12] reported some gypsum from Chagai (Gawalishtap gypsum in red shale of Washap formation) and Lasbela districts and some gypsum from Spin Tangi, Chamalang, etc of Balochistan Province.

Mineral Resources of Raskoh Magmatic Arc

The Raskoh arc includes many minerals (Figure 3) like Chromite, vermicu- 
lite, manganese, copper etc.

Chromite: It is associated with ultramafic rocks as layered intrusions or as ophiolitic sequences. It occurs as extensive layer in layered intrusives while irregular and podiform/lenses in dunite of ophiolitic rocks (Alpine type). Dunite occurs in the basal part of ophiolites i.e., in ultramafic tectonites and ultramafic cumulates [8]. Bunap and Rayo Ras Koh chromite (Kharan District) occurs in Nag-Bunap and Rayo Nai valley within a distance of $3 \mathrm{~km}$, located $30 \mathrm{~km} \mathrm{NW}$ of Kharan Kalat town. Chromite occurs as lenticular bodies or disseminations in the dunites. Nine small deposits with total reserves of 9664 tons near Bunap and 7 deposits with reserves of 355 tons near Rayo Nai were reported [12]. These deposits have been mined out and exhausted [5] but still mining are continuing indicating more deposits.

Vermiculite: It is mica like mineral that expands on heating to produce low density materials. It is used as light weight aggregate, thermal insulator, as a fertilizer carrier, soil conditioner in agriculture and as a filler and texturiser for plastics and rubber. It is not being used in Pakistan but can be exploited due to its availability. Vermiculite deposits are reported from Doki River on the northern edge of the western Raskoh. It occurs in cliff $160 \mathrm{~m}$ long, $140 \mathrm{~m}$ wide and 40 $\mathrm{m}$ high with reserves of $11 \mathrm{mt}$ [127]. The vermiculite contents vary from 5\% $20 \%$. Exfoliation tests at $775^{\circ} \mathrm{C}$ resulted in tenfold increase in the particle size [128]. The average analyses include $42 \% \mathrm{SiO}_{2}, 13.16 \% \mathrm{Fe}_{2} \mathrm{O}_{3}, 119.05 \% \mathrm{Al}_{2} \mathrm{O}_{3}$, $1.38 \% \mathrm{TiO}_{2}$ and $10.75 \% \mathrm{H}_{2} \mathrm{O}$ and $10.30 \% \mathrm{MgO}$ [129].

Gemstones: The chalcopyrite, malachite, azurite, chert, jasper, garnet, epidote, tourmaline, quartz and minerals of hornblend and pyroxene, etc are common gemstones found in the Ras Koh magmatic arc of central Balochistan basin.

Others: Manganese is reported from Sotkinoh hill (Ras Koh) (Kazmi and Abbas, 2001). The small deposit of gypsum (3.3 m thick) is reported from the red shale of Eocene Gawalishtap formation [12] [13]. Copper is reported from Tor Tangi of Ras Koh areas [104]. Various types of limestones and igneous rocks can be used for this construction and decorative stones.

\section{Mineral Resources of Wazhdad magmatic arc}

The recently discovered Wazhdad magmatic arc [14] [18] [96] hosts the ophiolitic and volcaniclastic rocks in the Wazhdad-Toe Koh and its vicinity show minor chromite, copper, soapstone and asbestos mineralizations (Figure 3). Granite of Washuk ophiolite is best for dimension and décor stones, besides this the best green to grey tuffaceous rocks of Wazhdad range are also significant for $\mathrm{cu}$ mineralization, decorative and dimension stones resources. Antimony showings are also found. Pl. see detail in the Siahan Range description as below.

\section{Mineral Resources of Hamun Mashkel basin (inter arc basin)}

The Hamun Mashkel basin includes the exposed eolian sands, alluviam gravel, conglomerate and sands. It subsurface may have coal or any significant lake deposits. 


\subsection{Mineral Resources of Southern Balochistan (Makran Siahan) Basin}

Mineral Resources of Makran and Siahan basin (Arc-Trench gap basin)

The reference [14] [16] [17] reported first time some new findings of Makran and Siahan ranges (Figure 2) (Figure 3).

Antimony and associated gold and silver mineralizations: The stibnite in the Qila Abdullah is located in the back arc basin (northern Balochistan) and all other stibnite localities (show very small deposits) are found in the fore arc basin (Southern Balochistan) (Figure 2) (Figure 3). Presence of antimony mineral stibnite and chalcedonic (cryptocrystalline texture) quartz show the epithermal type of mineralization. But the fluid inclusion study (homogenizing temperature) of some samples was analyzed by Rehan ul Haq Geoscience lab. Islamabad and show the possibility of mesothermal mineralization, only one sample of Grawag $(31 \mathrm{M} / 8)$ show the homogenizing temperature upto $333^{\circ} \mathrm{C}$, so it may be hypothermal. Antimony is found mostly in the strike slip faults, except the Jauder locality where it is found in thrust fault. The antimony mineralization originated due to dynamic (tectonic) activities and shearing in host rocks and deposited their lodes in the fractures, cavities, faults and gash fractures. This idea is proved by the metamorphism of shale into slates and intense faulting and folding in Siahan range and north Makran. According to [130] the antimony mineralization of Makran range is of epithermal origin. According to [131] the circulation of connate fluids in the flysch succession during dynamo thermal metamorphism related directly to the faulting is proposed as an origin for the antimony deposits. Stibnite (antimony trisulphide, $\mathrm{Sb}_{2} \mathrm{~S}_{3}$ ) is coated by yellowish mineral like sulphur. Gold, silver and sulphur mineralization are also enriched in this zone. Stibnite is shining lead grey, fine grained to fibrous and blady, metallic, subconchoidal to irregular and hardness is low (2 to 3). Gold and silver mineralizations associated with stibnite have been detected by the chemical analyses. The gold found is fine grained and disseminated with the antimony mineral. The carbonate mineral is calcite $\left(\mathrm{CaCO}_{3}\right)$. Quartz is cryptocrystalline to crystalline, translucent to transparent, subconchoidal and have commonly box like texture. Stibnite occurs in the form of veins, stringers and lenses in the faults especially oblique strike slip faults, gash fractures and shear zone in the Siahan, Hoshab and Panjgur formations. The thickness of the stibnite varies from $2 \mathrm{~mm}$ to $20 \mathrm{~cm}$. The stibnite vein is surrounded by quartz carbonate. Quartz is partially stained (maroon to red). Host rock or enclosing strata are also stained (brown, maroon to red) at the contact of antimony and quartz carbonate vein. Ferruginous alterations are also observed around the antimony vein. The thickness of the quartz carbonate vein varies from $2 \mathrm{~mm}$ to 2 metres. The nature and extent of quartz carbonate veins are discontinuous, lense shape, pinches and swells. Private and public sectors showed no interest for mining because of difficulties in access and also less thickness of stibnite vein. Some private sectors have started the mining at Jauder and Patkin but ended the 
work due to fair weather difficult accessibility, less thickness and discontinuous nature. The tentative estimated reserves of stibnite of known main localities of Siahan range are about 22,500 tons, by taking total $500 \mathrm{~m}$ length, $10 \mathrm{~cm}$ thickness, $100 \mathrm{~m}$ easy mineable depth and specific gravity about 4.5 . The author discovered most of the following localities. Jauder locality (35A/11) (Figure 2) is accessible from Washuk town and located on the northern slope of Koh Sabz Mountain range. Antimony-gold-silver is associated with the hanging wall of thrust fault $35^{\circ}$ dipping toward south. Vein is found in the sandstone unit of Panjgur formation. Antimony vein upto $20 \mathrm{~cm}$ thick, discontinous lense shape are observed. Now mining work is abandoned. Nearly 8 quarry (incline of 35 degree south) pits are observed. Quarry pits are less than 30 meters in depth but now they filled with scree/ overburden. But the local inhabitant told that the antimony vein upto $30 \mathrm{~cm}$ are recorded at the ending mining work. Hurain locality (35 A/11) (Figure 2) is accessible from Nag, Sabzab, and Panjgur town. Gold in this antimony veins are reported upto $8.81 \mathrm{ppm}$. This locality has many iron oxidize and quartz carbonate veins. Gokumb locality (35 A/11) (Figure 2) is located at the southern slope of Koh Sabz and accessible from Basima, Nag and Panjgur. Antimony vein (18 cm thick) is discontinuous lense shape. Host rock is Siahan shale. Gold upto $1.7 \mathrm{ppm}$ is also found. Kuchaki North locality (35 A/11) (Figure 2) is located on the southern slope of Koh Sabz and accessible from Basima, Nag and Panjgur town. Antimony vein $(10 \mathrm{~cm}$ thick) is discontinuous lense shape. Host rock is Siahan shale is observed in the strike slip fault trending northwest. In the southern and eastern vicinity the other $\mathrm{Sb}$ veins and stringers are also reported. Siminj locality (35 A/4) (Figure 2) is accessible from Panjgur, Washuk and Palantak towns. The antimony vein is $10-12 \mathrm{~cm}$ thick and 30 metres long and occurred as lense and discontinous nature. Mir Baig Raidgi locality (35 M/15) (Figure 2) is accessible from Panjgur, Washuk and Palantak towns. This vein is reported in the strike slip fault on the northern slope of Koh Sabz ridge continuation. It is $10 \mathrm{~km}$ from the Bibi Jan Ziarat (Langar). Siahan shale is the host rock. Safed Gilanchi locality (35 $\mathrm{M} / 15$ ) (Figure 2) is accessible from Washuk and Panjgur in fair weather season. Exposures of antimony, gold, quartz carbonate vein and associated mineralization in the strike slip fault are exposed at south from Bibi Jan Ziarat village. It is found on the northern slope of Koh Sabz ridge continuation. Its accessibility is slightly easy. There is no major rise and fall. It is situated in the base of ridge continuation. Host rock is Siahan shale. Machi Koh locality (35 M/15) (Figure 2) is accessible from Panjgur $85 \mathrm{~km}$ toward north in fair weather. Machi Koh antimony, gold, silver and quartz carbonate vein and associated mineralization have reported on the northern slope of Koh Sabz range. It is located on the north of Machi Koh. It is observed in the south eastern top of Kunarain Kaur. It is $10 \mathrm{~km}$ from Thal Waro area and approachable from Machi kaur. The accessibility is difficult and have two hour foot walk with high water fall (upto 20 meters). The host rock is Siahan shale. Palantak Koh locality (35 A/2) (Figure 2) is 
$1 \mathrm{~km}$ on northwest from Palantak town. The antimony, gold, silver and quartz carbonate and iron oxide vein and associated mineralization have been found on the western part of Palantak Koh. Host rocks are Siahan and Panjgur formations. Lidi locality (35 A/14) (Figure 2) is $10 \mathrm{~km}$ east of Washuk town. The Sb-Au mineralization is also associated with discontinuous quartz carbonate vein. Saghar locality (35 A/4) (Figure 2) is $20 \mathrm{~km}$ toward north from Panjgur town. It is situated on the southern slope of Rakhshan range. Antimony is disseminated in the quartz carbonate vein. The vein is in discontinous nature. Miani locality (35 A/13) (Figure 2) is $20 \mathrm{~km}$ toward south west from Washuk town. It is found on the northern slope of mountain range. Au-Sb is associated with discontinuous lenticular quartz carbonate vein. Other localities of stibnite associated with gold and silver hosted by quartz carbonate veins in toposheet $35 \mathrm{~A} / 11$ (Figure 2) are South Surmagi Patkin, North Surmagi Patkin, Haspi Patkin, Kulo Patkin, Hurain Patkin, Siagari, Kuchaki south, Ahmadab Kaur, Sor Jor Jauder, Mahmoodi Kaur, Kasig Kaur, Musa Kaur, Panir body east, Nagindap Damagi, Hashani Damagi, Hashani and Panir Body west.

Mercury and silver mineralizations: Mercury and silver mineralization are reported in the western and eastern Waro area (35 M/16) (Figure 2). Western Waro area is divided into three zones like southern, central and northern zones. Thal Waro Hg-Ag and associated mineralization have been found on the western plunge of doubly plunging syncline. Its accessibility is easy and on the Panjgur-Palantak track. Chemical results show highly anomalous mercury, silver and iron while slight anomalous $\mathrm{Pb}, \mathrm{Zn}, \mathrm{Ni}, \mathrm{Co}, \mathrm{Cu}, \mathrm{Mn}, \mathrm{Cd}$ and $\mathrm{Au}$. Mercury, silver, iron oxide, and other associated mineralization occur in the form of network of calcite veins, stringes and lenses in the fracture zone in Panjgur formation. These veins and stringes pinches and swells. Thickness of stringes and lenses vary from $0.5 \mathrm{~cm}$ to $15 \mathrm{~cm}$. Some calcite veins are also stained by yellowish brown to maroon iron colorations. In this area overturning of some beds and faults are observed. Mercury and silver mineralization is detected by the chemical analyses (Malkani 2011).

Iron oxidized zone: Many iron oxidized zone are observed in the reported area (Figure 2) like Waro (31 M/16), Jauder, Kasig, Musa Kaur, Sor Jor Jauder, and Hashani (35 A/11), Ahurag (31 M/12), Mazan Dastak (31 M/12), Palantak Koh (35 A/2), Sorgari and Siahgari (31 M/16), Sabz Village (35 A/12), 8 km SW of Panjgur (35 B/1), Mazarap Malhan, Kurki, Saghar, Soro and Phud Kush (35 A/3, 4, 7, 8), Baskroach (31 M/11), Hingol and many other areas. All of these areas have greater than $1 \mathrm{~km}$ length and more than 200 meters thickness. Host rock of these iron oxidized zone are Siahan shale, Hoshab shale, Zurati formation, and Panjgur formation. All these iron oxidized zones have network of quartz carbonate veins and stringes, carbonate veins and veinlets.

Meteorites: The reference Malkani [14] [16] [17] has reported possible meteorite first time in Pakistan, discovered from Soro and Phudkush area (35 A/3) (Figure 2) about 1 - $2 \mathrm{kms}$ toward south from the main track/road or east west 
jeepable track of Washuk to Panjgur (or Pajgur to Washuk). These meteorites are found in Eocene-Oligocene Siahan shale. These meteorites are represented by one big iron body just like a room sized big boulder with nearby one or two minor boulders located a few meters westward. These iron boulders have no relation to host rocks and seems to be meteorites. It is a hematite with green weathered colour.

Quartz carbonate veins: Many quartz carbonate veins (Figure 2) are observed in the iron oxidized zone. $\mathrm{Au}$ (gold)-Sb(antimony) mineralization are associated with quartz carbonate veins. $\mathrm{Hg}$ (mercury)- $\mathrm{Ag}$ (silver) of eastern Waro area (Fig.1c in Malkani 2011a) is also associated with quartz carbonate veins network. Some quartz carbonate localities are Sor Jor Jauder, Hashani, Musa Kaur and Kasig Kaur, (35 A/11), Haibatan Koh (35 M/16), Siagari Shand long and thick quartz vein (35 A/11), Safed Gilanchi, Mir Baig Raidgi, Machi Koh and Dauda Top (35 M/15), Baskroach Koh and Tank Zurati (31 M/11) Ahurag, Mazan Dastak, Sarkini, Mustaki, Nalingar, and Darag Parag (31 M/12), Grawag (31 M/8), Palantak Koh and Baran Koh (35 A/2), Miani and Lidi (35 A/14), Sabzab (35 A/12) and Saghar, Mazarap and Kurki $(35$ A/3, 4, 7, 8) and Surap (35 A/6). Other parts of Siahan and Makran also have many quartz carbonate veins. Siagari Shand quartz vein (35 A/11) (Figure 2) is located on the southern slope of the range. Its accessibility is difficult and can be made from Panjgur, Nag and Basima. Quartz vein is found in the imbricate fault trended east west. Quartz vein thickness is 2 meters with discontinous length of more than 500 meters. Quartz is crystalline to cryptocrystalline. Elongated hexagonal quartz crystal upto $1 \mathrm{~cm}$ are observed. The host rock is Siahan shale. Gold upto $0.458 \mathrm{ppm}$ is recorded. Eastern Waro locality (35 M/16) (Figure 2) is $6 \mathrm{~km}$ east from the western Waro locality. It consists of network of quartz vein and stringers and also have major ferruginous quartz carbonate vein trending northwest to southeast. On the west of this main vein the network of quartz veining are observed. Quartz of main vein is cryptocrystalline. Network of veining have subhedral quartz, however at the ending phase quartz are well developed which represent the late stage crystallization.

Pyrite mineralization: These mineralization are observed in the Durgi Kaur, Surap Kaur, and Wazhdad Kaur, etc. Durgi Kaur locality (35 A/3) (Figure 2) is $90 \mathrm{~km}$ toward north from the Panjgur and also accessible in fair weather. Durgi Kaur pyrite locality is also near the south-west of Palantak Tank. It is found in the calcareous sandstone. This sandstone is greenish grey, thin to thick bedded, hard and calcareous. Pyrite and chalcopyrite is observed as nodules and flakes in the host rock. Host rock is Panjgur formation. Wazhdad Kaur locality (35 A/6) (Figure 2) is $20 \mathrm{~km}$ far toward east from Palantak village and $70 \mathrm{~km}$ toward west from Washuk. Wazhdad Kaur pyrite/chalcopyrite mineralization is observed in the sandstone, shale, tuffaceous sandstone and shale of Zurati formation. It is found as nodules and flacks. Surap locality ((35 A/6) (Figure 2$)$ is $30 \mathrm{~km}$ toward east from Palantak village 
and $60 \mathrm{~km}$ toward west from Washuk. It is associated with iron oxide quartz carbonate vein in the Surap strike slip fault. Host rock is Zurati formation. Pyrite is observed as nodules and flakes.

Coal, carbonaceous shale and carbonaceous sandstone: Coal, carbonaceous shale and carbonaceous sandstone are observed in the Ahurag area (31 M/12) (Figure 2). It is $90 \mathrm{~km}$ northwest from Panjgur town. The thickness of coal and carbonaceous sandstone is $4 \mathrm{~cm}$ on the eastern side of Ahurag Kaur. On the western side of Ahurag Kaur 3 further layers of coal, carbonaceous shale and carbonaceous sandstone are observed. The extension of these coal seams is not known. Coal and carbonaceous shale is also reported by [12] from the Hoshab/Balgor area. However Balochistan desert is also important for exploration of lagoonal and lacustrine coal.

Sulphur: The Jiwani sulphur deposit $\left(25^{\circ} 05^{\prime} \mathrm{N} ; 71^{\circ} 47^{\prime} \mathrm{E}\right)$ are $20 \mathrm{~km} \mathrm{NW}$ of Jiwani and can be reached by boat from Jiwani but during the monsoon the best route is overland via Kuldan [132]. The sulphur deposit is nine inches thick discontinuous layer in dark grey clay near mud volcano. It is found within a few feet near the surface and some crystals are found in the overlying alluvial sand, cemented by gypsum, limonite and sulphur. The sulphur ranges from 43\% - 56\%. According to [105] the deposit is small. The Ganz sulphur deposit, about $1 \mathrm{~km}$ to the west of town Ganz which is a small fishing village about $15 \mathrm{~km}$ east of Jiwani, another similar deposit like Jiwani and also negligible deposit (Ahmed, 1969). The Pimpishka sulphur deposit $\left(26^{\circ} 45^{\prime} \mathrm{N}\right.$; $63^{\circ} 43^{\prime} \mathrm{E}$ ) is on the north side of salt playa at about $50 \mathrm{~km}$ to the SW of Panjgur [132]. The deposit is near the road about $5 \mathrm{~km}$ to the $S W$ of small peak named Pimpishka. Oligocene sandstone has been intensely leached in an area of about 50 square feet, leaving quartz grains in a matrix of sulphur and gypsum. The sulphur ore contains less than $20 \%$ sulphur which fills fractures in the rocks near the spring. Origin is similar to Sanni sulphur. The Karghari sulphur deposit $\left(25^{\circ} 27^{\prime} \mathrm{N} ; 64^{\circ} 09^{\prime} \mathrm{E}\right)$ is near Gokurt on the Makran coast. Further sulphur deposit was also reported near Khan Berar at the southern end of Haro range about 5km from the sea coast near the Porh River [132]. Both sulphur and salts are associated with saline springs are found in the rocks of Miocene-Pliocene age [8].

Bed rock and aggregate resources: The large reserves of bed rock resources like shale, slates, and sandstone, with negligible showings of limestone, the aggregate resources like gravel and sands are observed in the area. The sandstone of Zurati, Panjgur and Shaigalu formations, and limestone of Wakai and Jiwani formations though very rare but are significant for construction materials [14].

Water resources: Channel (stream) alluvium deposits, Quaternary gravel deposits and Pleistocene Kech/Kamerod/Jiwani formation, sandstone unit of Talar, Panjgur and Zurati formations play a significant role for ground water resources. Main tributaries of the reported area are of Rakhshan river, Mashkel 
rud. Bibi Tank, Palantak Tak, Kurki, Mazarap, Greshag Kaur, Regintak, Kech, Hingol, Haro, etc. are ephemeral stream. Some hole are drilled and installed for domestic water supply in the Panjgur town. These holes are drilled on the banks of Rakhshan River. The water is fresh to slightly brackish. Here the water bearing rocks are stream channel, quaternary gravels and Kamerod/Kech conglomerate. In and vicinity of Panjgur town, the kareezes are the main source of cultivation, vegetation, and date farming. Kareezes are digged and pitted in the quaternary fan and terrace gravels and Kech formation. The water quality is slightly brackish to brackish. In the dispersed villages namely Grawag, Palantak, Nok Chah, etc, the artificial pitted wells, tributaries water and springs are source of water for domestic supply. Artificial holes are pitted in the alluvium and water table varies from 5 metres to 50 metres. Rains are the main source for cultivations. One drilled (cased) hole are observed in Tank Zurati area (31 M/11) giving low pressure peizometric water (slightly brackish), may be completed by Asian development Bank (known by local inhabitants). Tank Zurati is best place for the construction of small dam on the Mashkel rud for the cultivation. More than 100 gorges are also suitable for smaller dam for water storage for cultivation and population which can play best for the development of the area. In short, these areas can be converted into cultivation and vegetation by efforts. In the Panjgur town the channel gravels give fresh water for domestic supply. The tube wells are observed on the both banks of Rakhshan River. Very low quality and quantity water is also available from the springs in mountaineous areas. This low quantity and quality may be due to presence of shale and salts. The Makran has mostly mountainous areas sandwiched by many plains and semiplains areas where dam construction is feasible [14].

Gemstones: The diamond like white beautiful quartz crystals are commonly found as veins in the Eocene-Pliocene strata of Makran and Siahan ranges of Balochistan basin. The gemstones can be found in the placer deposits.

Others: Petroleum seep is reported in 1939 by Clapp near the boarder of Iran near to Grawag area called as Kwash seep [12]. Further two water springs (negligible quantity) coated by petroleum lustrous material was observed in the Gish Kaur Bulleda valley near the village of Koshk 31 N/3 district Turbat and in the Sor Jor Jauder area 35 A/11 district Kharan [14]. Mud volcanoes of cold muddy water also show anomalous gas like methane upto $74.5 \%$ and nitrogen upto $13.8 \%$ near Ormara [12]. Many salts deposits and lakes are located in the vicinity of Makran coast and Hamun i Mashkel area. Alum may also be associated with these salts [14].

\subsection{Revised Stratigraphy and Mineral Resources of Western Indus Suture (WIS; Contact of Balochistan Basin: A Part of Tethys and Indus Basin: A Part of Gondwana Southern Hemisphere)}

The western Indus suture is a suture between the Balochistan basin (a part of 
Tethys) and Indus Basin (an aprt of Gondwana). The western Indus suture is jointed just east of Balochistan basin that is the reason being described here. It includes the ophiolitic mélanges and sedimentary Mesozoic and Cenozoic sedimentary sequences.

Revised Stratigraphy of Western Indus Suture (WIS Lasbela-Khuzdar Quetta-Muslimbagh-Zhob-Waziristan), Pakistan: The Bela Volcanic Group is $190 \mathrm{~km}$ long and $20 \mathrm{~km}$ wide, extending from Ornach in the north to Windar in the south. Volcanic rocks are subordinate in the north of Ornach and dominate in the south. It consists of intermixed volcanic and sedimentary rocks. The volcanic rocks are mainly basalt, lava, coarse grained agglomerate and bedded tuff. The lava flows are commonly pillowed and spilitic. Most of the weather reddish brown or green, but the more massive types weather black and are difficult to distinguish from intrusions [12]. Rocks are altered and fractured filled with epidote and carbonate. Phenocrysts of augite with rims of chlorite are common, amygdules of calcite and microlites of feldspar are abundant. Interlayered sediments are shale, marl, limestone, conglomerate, and radiolarian chert. This group overlies the Windar group conformably (west of Mor range), and is overlain unconformably by the Oligocene Nal limestone (Northwest of Bela). Its age is Cretaceous [12]. Bela Ophiolite Complex consists of mainly ultrabasic, basic, and intermediate compositions. Granitic rocks are rare. The true granite is in the form of conglomerate pebbles. The ultrabasic rocks are altered pyroxenite, serpentinized peridotite and amorphous and sheared serpentrinite. The rocks of intermediate compositions are diorite and gabbro. The gabbro is dark green rock spotted with large crystals of white feldspar which is kaolinized. Some types are pegmatitic and exhibit crystals upto 4 inches across of biotite and pyroxene. A small body of the granodiorite located in the west of Porali river, $10 \mathrm{~km}$ south of Wad. Concordant and discordant intrusions are found. Iridescent soapstone found from Nal area. Muslimbagh Ophiolite Complex consists of mainly serpentinized ultrabasic rocks that include saxoniter, dunite and pyroxenite. It also consists of dolerite, gabbro, and diorite but these seem slightly later phase. The age is Late Cretaceous-Early Paleocene [12] [133]. Geological formations associated with igneous rocks are widely $(10 \mathrm{~km})$ exposed in the Indus Suture zone are Bela volcanics (Bela volcanic group/Porali agglomerates/Porali volcanic conglomerate), Bela ophiolite, Mor intrusives, Konar mélange, Zhob ophiolite, Zhob mélange, Bagh complex, Waziristan ophiolite mélange, Twin sister soda dolerite and Pir Umar basalts, and Triassic Khanozai group (Gwal and Wulgai formations), Jurassic Alozai group, Cretaceous Parh group (Sembar, Goru and Parh formations), Fort Munro group (Mughalkot or Bibai formation), and Paleocene Sangiali group (Sangiali, Rakhi Gaj and Dungan formations in Sulaiman/mddile Indus) and Ranikot (Khadro, Bara and Lakhra in Kirthar/lower Indus), Thar and Bad Kachu formations and Gidar Dhor group, Eocene Chamalang (Ghazij) and Kahan and Kirthar groups, Oligocene-Pliocene Vihowa group, Pleistocene-Holocene Sakhi Sarwar group, subrecent and Recent surficial alluvial, colluvial and eaolian deposits. 


\section{Mineral Resources of Western Indus Suture (WIS; Lasbela-Khuzdar Quetta-Muslimbagh-Zhob-Waziristan), Pakistan}

After the Chagai magmatic arc, the Indus Suture shows significant economic commodities (Figure 3).

Chromite: Chromite is first reported by [84] and its mining was started in 1903 in the Khanozai area and extended to Muslimbagh in 1915 and in early twenties mining started in Sra Salwat area, $29 \mathrm{~km}$ south of Muslimbagh. The following deposits like Muslimbagh chromite (Qila Saifullah District) and Wad, Sonaro and Ornach chromite (Khuzdar District) are significant [134]. Muslimbagh area chromite (Qila Saifullah District) extends from Gwal to Nisai a distance of about $100 \mathrm{~km}$. This region shows the best and largest deposits in Pakistan. Thrust blocks of various sizes are scattered in the Muslimbagh valley, however large outcrops are exposed near Muslimbagh and Khanozai areas. Two large bodies namely Saplai Tor Ghar and Jang Tor Ghar located south of Muslimbagh town, show a classic sequence of ultramafic tectonites, ultramafic and mafic $\mathrm{cu}-$ mulates, a dyke complex and a dolerite dyke swarm. Chromite occurs in the serpentinised dunites of ultramafic tectonites and cumulates in different forms and shapes. There are massive ore surrounded by banded ore, grape shot ores, banded deposits of disseminated ores, cigar-shaped ore bodies, dyke like ore bodies upto $100 \mathrm{~m}$ long and thin wiggly, irregularly shaped bodies. The reserve in these types of ore bodies varies from $100-15,000$ ton [135] [136] [137]. The Muslimbagh chrome ores are aluminous chromite. The chrome of Jang Tor Ghar ore is of metallurgical grade. The Khanozai ore shows $\mathrm{Cr}_{2} \mathrm{O}_{3} 49.3 \%-52.6 \%$ and Cr:Fe ration 2.7 - 3.5:1, Jang Tor Ghar ore shows $\mathrm{Cr}_{2} \mathrm{O}_{3} 48 \%-57 \%$ and $\mathrm{Cr}: F e$ ration 3 - 3.7:1, Saplai Tor Ghar ore shows $\mathrm{Cr}_{2} \mathrm{O}_{3} 44 \%-52.5 \%$ and $\mathrm{Cr}: \mathrm{Fe}$ ration 3:1, and Nisai ore shows $\mathrm{Cr}_{2} \mathrm{O}_{3} 39 \%-49 \%$ and Cr:Fe ration $2.1-2.6: 1$. The extension of present pitting shows much more reserves than above mentioned. Zhob area chromite (Zhob District) is close to Zhob town in the north. Thrust blocks of various sizes are found in the Zhob area. The Zhob chrome ores are aluminous chromite. Naweoba and Zizha (near Zhob town) is refractory grade while Jang Tor Ghar ore is metallurgical grade. The Naweoba and Zizha ore shows $\mathrm{Cr}_{2} \mathrm{O}_{3} 36.7 \%$ - 46.5\% and $\mathrm{Cr}$ :Fe ration 2.9:1. Due to relatively less exposures, the deposit seems to be small. Wad, Sonaro, Ornach chromite (Khuzdar District) region contains the largest ophiolitic complex in Pakistan covers a long distance of about $320 \mathrm{~km}$. The Bela complex is mainly comprised of mega mélanges, tectonically wedged in between the thrust sheets of Jurassic and Cretaceous sedimentary rocks [138]. The ophiolites include fragments and blocks of peridotite, dunite, minor pyroxene, serpentinite, diabase, gabbro and lava flows. The Sonaro block extend over $116 \mathrm{sq} \mathrm{kms}$ and show a complete sequence of ultramafic tectonites at base and ranging upto pillow lavas and sediments at the top. The ophiolite contains lenticular or disseminated bodies of chromite. The main chromite deposits are near Sonaro, Baran Lak, Drakalo and Greshak area of Khuzdar, while [139] identified more than 15 pods. Open pit mining is in 
progress [8].

Magnesite: There are several occurrences in the ophiolitic thrust belt showing small deposits or trivial showings. Magnesite from Nisai, Spin Tangi, Shabi Ghundi (Muslim Bagh), Tleri Mid Jan, Sra Salwat (Muslim Bagh), Zhizha, Loya Na Pani, Sinchi Md Khan (Wad) and Baran Lak (Bela) area are reported. The very small deposits like 60,000 tones of Magnesite ( $\mathrm{MgO} 43.38 \%-45.4 \%$ ) of Spin Kan $\left(30^{\circ} 47^{\prime} \mathrm{N} ; 68^{\circ} 06^{\prime} \mathrm{E}\right)$ in serpentinised ultramafic rocks of Bagh ophiolitic thrust, 6000 tones of magnesite ( $\mathrm{MgO} 38.04 \%$ - 42.36\%) deposit of Shabi Ghundi $\left(30^{\circ} 48^{\prime} \mathrm{N} ; 68^{\circ} 00^{\prime} \mathrm{E}\right)$ in serpentinised ultramafic rocks of Bagh ophiolitic thrust, very small deposits of magnesite of Tlerai Mohd Jan $\left(30^{\circ} 53^{\prime} \mathrm{N} ; 67^{\circ} 42^{\prime} \mathrm{E}\right)$ in serpentinised ultramafic rocks of Zhob ophiolitic thrust, very small deposits of magnesite of Zizha $\left(31^{\circ} 3^{\prime} \mathrm{N} ; 69^{\circ} 37^{\prime} \mathrm{E}\right)$ in serpentinised ultramafic rocks of Bagh ophiolitic thrust, very small deposit of magnesite ( $\mathrm{MgO} 32.8 \%$ ) of Kakru $\left(27^{\circ} 43^{\prime} \mathrm{N}\right.$; $\left.66^{\circ} 09^{\prime} \mathrm{E}\right)$ occurs as vein in serpentinised ultramafic rocks of Bela ophiolitic thrust, very small deposit of magnesite ( $\mathrm{MgO} 32.84 \%-44.56 \%$ ) of Loya $\mathrm{Na}$ Pani $\left(27^{\circ} 15^{\prime} \mathrm{N} ; 66^{\circ} 20^{\prime} \mathrm{E}\right)$ occurs as vein in serpentinised ultramafic rocks of Bela ophiolitic thrust, 20,000 tones of magnesite (MgO 18.08\%) of Baran Lak $\left(26^{\circ} 59^{\prime} \mathrm{N}\right.$; $\left.66^{\circ} 18^{\prime} \mathrm{E}\right)$ occurs as vein in serpentinised ultramafic rocks of Bela ophiolitic thrust, very small deposit of magnesite of Sinchi Bent $\left(26^{\circ} 30^{\prime} \mathrm{N} ; 26^{\circ} 21^{\prime} \mathrm{E}\right)$ occurs as vein in serpentinised ultramafic rocks of Bela ophiolitic thrust, 16,000 tones of magnesite ( $\mathrm{MgO} 46.49 \%)$ of Sra Salwat $\left(30^{\circ} 40^{\prime} \mathrm{N} ; 67^{\circ} 53^{\prime} \mathrm{E}\right)$ occurs in Eocene dolomite unconformity overlying the Zhob ophiolites, very small deposit of magnesite of $\mathrm{Nal}\left(27^{\circ} 41^{\prime} \mathrm{N} ; 66^{\circ} 11^{\prime} \mathrm{E}\right)$ occurs as replacement veins in limestone of Shirinab Formation of Bela ophiolitic thrust [8] [140]. The reference [141] reported 1.23 million tons of magnesite from Khuzdar area, the localities with reserves in tons are Sonoro (582 tons), Godar (656 t), Sokand Ghar (862 t), Baran Luk south (8905 t), Baran Lak (17,390 t), Baran Lak east (23,375 t), Baran Lak north (19,728 t), Chokri Ghor (25,712 t), Chrome mine (3836t), Pahar K. Bidrang south (3362), Pahar K. Bidrang (25,935), Khushal east (2156 t), Abui Ka Tang (133,500 t), Khushal west (9407 t), Khushal central (14,796 t), Ustam Butt west (41,454 t), Ustam Butt east (43,555 t), Gangu (816,000 t), Karku (31,970 t), Lukh (1267 t), Lukh north (2115 t) and Bhanbhori Na Kund (840 t).

Barite: It is being used for weighting agent in drilling mud. It is also used for barium chemicals, white pigment and in paper industry. It is deposited by hydrothermal solutions. The barite deposits of Balochistan were discovered by [142]. These deposits extend from Khuzdar to Uthal [143] [144] [145]. It is found in the Shirinab, Zidi and Windar formations (Triassic-Jurassic) forming bedded replacement or veins. The deposits of Gunga (near Khuzdar) and Duddar in Las Bela district have over 12 million tons of barite [146]. The Gunga deposit is being mined by joint venture of Balochistan Government and Pakistan Petroleum Ltd. Barite deposits are estimated about $30 \mathrm{mt}$. The production from these deposits meets the total requirement for drilling and barium based chemical plants. Further the nodules of barite are commonly found in the Cretaceous 
Sembar shale. Barite from Las Bela area like Naka Pabni, Gacheri, Dhoro, Siro Dhoro, Bankhari and Kundi; Khuzdar area like Gunga, Shekran and Monar Talar have reported.

Platinum group elements (PGE)-Muslimbagh area: Platinum group elements (PGE) have been reported in the chromitites from the Muslimbagh ophiolites of Saplai Tor Ghar. Preliminary study show the primary deposits but not economic and however there are chances of economic placer deposits Nakagawa M., Siddiqui R.H., Hoshino K. 1996. Prelim. Assess. On ultrmafics related mineralization of Muslim Bagh ophiolites. Proc. Geosc. Colloquium Geosc. Lab. GSP, 16,195 - 212 [147]. The two samples from tectonites show ppb values of Os 24, 36; Ir 30, 45; Ru 85, 130; Rh 10, 13.3; Pt 35, 33; Pd 15, 46; Au 2.5, 7.4; Total PGE 179, 303 The three samples from cumulate show ppb values of Os 41,13,6; Ir 35, 24, 7.7; Ru 100, 55, 9; Rh 16.8, 11.1, 4.5; Pt <5, <5, 18; Pd 4, 3, <2; Au 9.1, 7.4, 1.3; Total PGE 202, 111, 47, CI-chondrite value of OS 514, Ir 540, Ru 690, Rh 200, Pt 1020, and $\mathrm{Pd} 545$. Chondrite is a stony meteorite contains chondrule (small rounded bodies of olivine or enstatine) embedded in a fine grained matrix of pyroxene, olivine and nickel-iron [148].

Asbestos: Small deposits and showing of chrysotile and tremolite asbestos are found in serpentines of the ophiolitic complex near Naweoba (Zhob) [5], Taleri Mohd Jan (Muslimbagh) [5] and Wad Khuzdar.

Lead and Zinc: The major lead-zinc and barite deposits are discovered by Geological Survey of Pakistan from the Las Bela-Khuzdar region [139] [144]. The mineralization is found in the upper part of Lower Jurassic Shirinab Formation. Main deposits are Shekran, Ranj Laki, Malkhor (NW of Khuzdar), Mithi, Gunga, Surmai (SW of Khuzdar, and Duddar (SE of Bela). Gunga, Surmai and Duddar deposits have been explored and evaluated in detail. The Gunga and Duddar deposits occur in the upper part (Anjira member) of the Shirinab Formation and are of sedimentary exhalative (Sedex) type. The deposits are found between major faults which have many subsidiary smaller faults. The Duddar deposit has multiphase mineralization and overprinting of later phases on the earlier ones. At Duddar, the barite may be exhalative and formed on sea floor where as the sulphide mineralization is syndiagenetic and formed by displacement or replacement of the host siliceous fluids. Deformation of sulphide layering shows that ore was formed before early emplacement and there fore preTertiary. Proved reserves of 6.38 million ton/mt and inferred reserves 3.43 mt with $11.34 \%$ Zinc and 2.01\% lead have been established [145]. The Gunga deposit, $11 \mathrm{~km}$ SE of Khuzdar, is hosted by Early to Middle Jurassic Anjira Formation. The mineralization is stratiform, stratabound, open space filling type. The zone extends over a distance of $1200 \mathrm{~m}$ and easily distinguished as silicic gossans. The gossans contains $3 \%-4 \% \mathrm{~Pb}$ and $\mathrm{Zn}$. The deposit was explored through 14 drill holes. The ore body contains over $6 \% \mathrm{Zn}$ and $1.5 \% \mathrm{~Pb}$, with proven reserves of $6.5 \mathrm{mt}$, probable reserves of $3.0 \mathrm{mt}$, and possible reserves of $3.3 \mathrm{mt}$ [139] [143]. The Surmai deposit is located $1 \mathrm{~km}$ South of Gunga depo- 
sit and hosted by Loralai Formation and is of Mississippi valley type. It has been explored by GSP and JICA and reserves of $2.93 \mathrm{mt}$ of ore with average content of $6.5 \%$ have been established. This deposit also contains $10-20 \mathrm{gm} /$ tone of Silver [146] [149].

Manganese ore: Manganese deposits occur as marine, chemically precipitated sedimentary ores, as secondary enrichment deposits and as hydrothermal deposits. The deposits of manganese ore in Pakistan are associated with volcanic rocks in the ophiolitic thrust belt [150]. In the Bela ophiolitic thrust belt, lenticular manganese ore bodies occur in ferruginous and siliceous horizons overlying basaltic pillow lavas. The more important localities are Kharari Nai $\left(25^{\circ} 54^{\prime} \mathrm{N} ; 66^{\circ} 45^{\prime} \mathrm{E}\right.$; $\left.35 \mathrm{~K} / 9\right) 34,000$ tons of two separate pods of 70 and 7 square metres (Abbas 1980a) of Manganese 42\% [151], Siro Dhoro (26 $16^{\circ} \mathrm{N} ; 66^{\circ} 33^{\prime} \mathrm{E}$; 35J/11) 950,000 tons irregular veins and lenses ranges from $1-6$ inches in thickness [152] (Master 1960) of Mn 36\% [151], Sanjro Dhoro (26 $28^{\prime} \mathrm{N} ; 66^{\circ} 26^{\prime} \mathrm{E}$; 35J/7) 65,000 tons mineralization in discontinous lenticular bodies having $0.5 \mathrm{~km}$ strike length and 1 - 5 metres thickness [5] of Mn 15\% [151], Bhampani Dhoro $\left(26^{\circ} 11^{\prime} \mathrm{N} ; 66^{\circ} 33^{\prime} \mathrm{E}\right.$; $\left.35 \mathrm{~J} / 2\right) 5800$ tons the ore is square shape in an open pit [12] of Mn 41\% [151], Gadani ridge ( $26^{\circ} 05^{\prime} \mathrm{N}$; $\left.66^{\circ} 34^{\prime} \mathrm{E} ; \mathrm{Mn}, 48 \%\right)$ and Dadi Dhoro $\left(26^{\circ} 05^{\prime} \mathrm{N} ; 66^{\circ} 37^{\prime} \mathrm{E} ; \mathrm{Mn}, 35 \%\right)$. Most of the production comes from Las Bela region. Other localities are in Zhob area like Naweoba and Waltoi rud localities, Las Bela region like Kohan Jhal, Haji Khan Bent, Sanjro, Khabri, Siro and Khan Kheo localities.

Buildings, construction stones and Decorative stones: Large reserves of recrystallised limestone and marble are being used from the Indus Suture zone due to near road location to main industrial city Karachi. Large reserves of good quality gabbro are found in Muslimbagh-Nisai area. Dolerite dykes from several localities provide jet black slabs for tiles and wall facings. Several kinds of multicolored, exquisite brecciated rocks are mined from the Bela and Kanar mélanges in Bela-Khuzdar area. Several varieties of fossiliferous limestone with beautifully oriented designs of foraminifers, mollusk shells and quartz and calcite veins, ranging in shade from cream to fawn, light brown to shades of grey occur extensively in the Paleocene to Eocene sequences in Las Bela area. These are being mined and marketed under erotic trade names such as Golden, Trevera, Boutecenne, Verona, Black and Red Zebra, Oceanic etc. The private sector exclusively deals with the production, processing and marketing of marble and other decorative stones [8].

Gemstones: The many beautiful gemstones like fluorite, chalcopyrite, malachite, azurite, chert, jasper, garnet, epidote, tourmaline, quartz, bronzite and other minerals of hornblende and pyroxene group, serpentine, natrolite, etc are common gemstones found in the western Indus Suture. Chert and jasper beds are found in the Jurassic Chiltan limestone in the shirinab Range located between the Shirinab and Khad Kucha valleys. Further chert and jasper is also found in the Cretaceous Mughalkot Formation of Tor Thana area of Loralai. 
Best diamond type quartz crystals are found in the Cretaceous Mughalkot Formation of Gharwandi (Alu Khan Kach) area of Kingri, Musa Khel and quartz and other diverse beautifulgemstones from Zhob, Lasbela and Khuzdar areas. This suture is the contact of Balochistan basin and Indus basin. The worker may be encouraged for stream sediments, alluvial and placer washing methods, alluvial for collection of gold, gemstones, REEs and heavy minerals like monazite, zircon, rutile, ilmenite, etc. The reference [153] reported significant diverse gemstones from Muslimbagh area like malachite, azurite, natrolite, serpentine and talc from ophiolitic rocks, epidote, chrysochola, natrolite and marble from metamorphic and poor quality gems like jasper, quartz, green chert, quartz, calcite, agate and amethys from sediments. These gemstones are expected in other areas of western Indus suture.

Others: The iron ore from Las Bela-Khuzdar region of Western Indus Suture (WIS) like Shekran and Mona Talar, while Zhob region like Naweoba and Inzarki [5], minor graphite showings like stringes and lenses in Shirinab Formation from Sheikh Wasil area $\left(29^{\circ} 55^{\prime} \mathrm{N} ; 66^{\circ} 36^{\prime} \mathrm{E}\right)$ and in the west and northwest of Quetta [12], soapstone showings in the ophiolitic rocks from Zhob valley like Gach Inziakai, Shinghar hill, Zamankar nala (Walgai Oba) and Bahram Khel localities, the copper from Sange Gar, Zizha, Shin Ghar and Otman near Jalat Killi of Zhob area, Nisai and Tor Ghar of Muslimbagh area and Ann Dhoro and Paha Dhoro and other places of Las Bela area have been reported [8] [154] [155] the mercury from Gunga and Duddar area, Nickel from Muslimbagh area, Niobium and platinum from Muslimbagh area, phosphate from Chapar area (WNW of Kalat), and sulphur deposit $\left(29^{\circ} 06^{\prime} \mathrm{N} ; 66^{\circ} 21^{\prime} \mathrm{E}\right)$ of Chapar near Manguchar about $25 \mathrm{~km}$ NW of Kalat, large deposits of dolomite occurs in Jurassic Chiltan formation of Chiltan Range-Ziarat Nala ( $\mathrm{MgO} 20 \%, \mathrm{CaO} 32 \%, 250 \mathrm{mt}$ ), quartz from Zhob and Las Bela and its vicinity areas, and jasper from Las Bela area [8] and minor showings of soapstone are found in the Shirinab formation of Khad Kuch area of Mastung.

Rare Earth elements (REE) and thorium exploration in Balochistan basin and western Indus Suture: The Rare earths are extensively used for information technology, computer, clean energy systems, health care, defense production, advanced transportation services, rechargeable batteries, catalytic converters, fluorescent lightings, cell phone and many others. The applied as well as research sector organizations of developed countries are the major consumers of REEs as they increase the efficiency of solar cells, wind turbines and other renewable energy systems. The Balochistan Basin hosts different type of igneous rocks like acidic, intermediate, basic and also ultrabasic intrusive and volcanic. Further Balochistan Basin also hosts the vast sedimentary marine and terrestrial bed rocks, Quaternary alluvial, colluvial and eolian deposits in which REEs can be explored. REE are commonly associated with other mineral deposits like iron, fluorite, carbonate, etc. which are also found in Balochistan Basin and adjoining Indus Suture areas. The rare earth elements 
are associated with heavy minerals (for example in India) like ilmenite, sillimanite, garnet, zircon, monazite and rutile, collectively called beach sand minerals (BSM). The Balochistan Basin has a long east west trending coastal belt and oceanic beach sands and oceanic clay in the southern Makran in which REE can be explored. Further the pink coloured beach sand is common in sea coast of Balochistan basin like Gawader pink beach sand which is indication of zircon, monazite and other heavy minerals.

Global and national Geoparks installation in Balochistan basin and western Indus Suture, Museum and Geo-assets: Balochistan Basin is represented by Cretaceous to Recent Tethys geoheritages [12] [156]-[165], while other regions of Pakistan host Gondwanan as well as Laurasian geo-heritage. Balochistan Basin includes significant diverse mineral rsources hosted by diverse sedimentary, igneous and metamorphic rocks. Balochistan basin hosts mud volcanoes and meteorites unique in Pakistan and other geo-assets which needs protection of these paleogeoheritage as national and global geoparks which is an innovation for the sustainable development of science and Pakistan. A new island was emerged during the 1945 earthquake [166], mud crater extrusion [167] and deformation of Makran coast [168]. Previously most of the Balochistan basin was considered flysh marine deposits but now the northern part of Kakar-Khorasan basin (northern Balochistan basin) yielded terrestrial rhinoceroses Pakitherium shagalai [80] [81] [82] from Eocene Shagala Formation of Shagala Group located in Shagala-Kamardin Karez area of Zhob district, Balochistan Province, Pakistan. The fossils of these rhinoceroses [80] [81] [82] from Balochistan basin, and titanosaurian sauropods [169] [170] [171] [172] and theropods [173], mesoeucrocodiles [173], pterosaurs [173] and other recently discovered biotas [82] found from Pakistan are hosted in museum of the Geological Survey of Pakistan, Quetta, Balochistan. Further the sites of Mesozoic diverse footprints/tracks and trackways of diverse dinosaurs [82] [174] [175] need their protection.

\section{Conclusion}

Balochistan basin consists of Cretaceous to recent sediments, diverse igneous rocks and low grade metamorphics. Balochistan basin is a leading basin which consists of very significant mineral deposits especially copper (associated some gold, silver, molybdenum). Some commodities are being utilized and exploited but most of the commodities are waiting for their utilization and developments for the area, Balochistan and ultimately for the development of the Pakistan.

\section{Conflicts of Interest}

The author declares no conflicts of interest regarding the publication of this paper.

\section{References}

[1] Jan, M.Q. and Gauhar, S.H. (2013) Earth Sciences and Mineral Exploration History 
of Pakistan with Reference to Khyber Pakhtunkhwa and Its Adjacent Tribal Areas. Abstract Volume, Sustainable Utilization of Natural Resources of the Khyber Pakhtunkhwa and FATA, February 11, Peshawar, Pakistan. Journal of Himalayan Earth Sciences, Special volume 2013, 15-16.

[2] Gee, E.R. (1949) Mineral Resources of North West India. Geological Survey of Pakistan, Record, 1, 1-25.

[3] Heron, A.M. (1950) Directory of Economic Minerals. Geological Survey of Pakistan, Record, 1, 1-69.

[4] Heron, A.M. and Crookshank, H. (1954) Directory of Economic Minerals of Pakistan. Geological Survey of Pakistan, Record, 7, 1-146.

[5] Ahmad, Z. (1969) Directory of Mineral Deposits of Pakistan. Geological Survey of Pakistan, Record, 15, 1-200.

[6] Gauher, S.H. (1969) Economic Minerals of Pakistan: A Brief Review. Geological Survey of Pakistan, Pre Publication Issue, 88, 1-110.

[7] Ahmad, Z. and Siddiqui, R.A. (1992) Mineral and Rocks for Industry. Geological Survey of Pakistan, Quetta, 325 p.

[8] Kazmi, A.H. and Abbas S.G. (2001) Metallogeney and Mineral deposits of Pakistan. Published by Orient Petroleum Incorporation, Islamabad, Graphic Publishers, Karachi, Pakistan, 264 p.

[9] Malkani, M.S. and Mahmood, Z. (2016) Mineral Resources of Pakistan: A Review. Geological Survey of Pakistan, Record, 128, 1-90.

[10] Malkani, M.S. and Mahmood, Z. (2017) Mineral Resources of Pakistan: Provinces and Basins Wise. Geological Survey of Pakistan, Memoir, 25, 1-179.

[11] Malkani, M.S., Alyani, M.I., Khosa, M.H. Somro, N., Arif, S.J., Tariq, S., Saeed, F., Khan, G. and Faiz, J. (2016) Mineral Resources of Pakistan-An Update. Lasbela University Journal of Science and Technology, 5, 90-114.

[12] Jones, A.G., Manistere, B.E., Oliver, R.L., Willson, G.S. and Scott, H.S. (1961) Reconnaissance Geology of Part of West Pakistan (Colombo Plan Co-Operative Project Conducted and Compiled by Hunting Survey Corporation). Government of Canada, Toronto, $550 \mathrm{p}$.

[13] Ahmad, Z. (1975) Directory of Mineral Deposits of Balochistan. Geological Survey of Pakistan, Record, 36, 1-178.

[14] Malkani, M.S. (2011) Stratigraphy, Mineral Potential, Geological History and Paleobiogeography of Balochistan Province, Pakistan. Sindh University Research Journal (Science Series), 43, 269-290.

[15] Malkani, M.S., Mahmood, Z., Shaikh, S.I. and Arif, S.J. (2017) Mineral Resources of Balochistan Province, Pakistan. Geological Survey of Pakistan, Information Release, $1001,1-43$.

[16] Malkani, M.S. (2004) Mineral Potential of Siahan and North Makran Ranges, Balochistan, Pakistan. In: Abstract Volume, National Conference on Economic and Environmental Sustainability of Mineral Resources of Pakistan, 20-22 July, 2004, Baragali, Pakistan, 46-47.

[17] Malkani, M.S. (2004) Stratigraphy and Economic Potential of Sulaiman, Kirthar and Makran-Siahan Ranges, Pakistan. In: Hussain, S.S. and Akbar, H.D., Eds., Fifth Pakistan Geological Congress, Abstracts volume, National Geological Society of Pakistan, Pakistan Museum of Natural History (Pakistan Science Foundation), Islamabad, Pakistan, 14-15 April 2004, 63-66. 
[18] Malkani, M.S., Mahmood, Z., Arif, S.J. and Alyani, M.I. (2017) Revised Stratigraphy and Mineral Resources of Balochistan Basin, Pakistan. Geological Survey of Pakistan, Information Release, 1002, 1-38.

[19] Malkani, M.S. (2010) Updated Stratigraphy and Mineral Potential of Sulaiman Basin, Pakistan. Sindh University Research Journal (Science Series), 42, 39-66.

[20] Malkani, M.S., Mahmood, Z., Alyani, M.I. and Shaikh, S.I. (2017) Revised Stratigraphy and Mineral Resources of Sulaiman Basin, Pakistan. Geological Survey of Pakistan, Information Release, 1003, 1-63.

[21] Malkani, M.S., Mahmood, Z., Somro, N. and Shaikh, S.I. (2017) Revised Stratigraphy and Mineral Resources of Kirthar Basin, Pakistan. Geological Survey of Pakistan, Information Release, 1010, 1-59.

[22] Malkani, M.S., Khosa, M.H., Alyani, M.I., Somro, N., Zafar, T., Arif, J. and Aleem, M.Z. (2017) Revised Stratigraphic Setup and Mineral Deposits of Kirthar Basin (Lower Indus Basin), Pakistan. Lasbela University Journal of Science and Technol$o g y, 6,54-84$.

[23] Malkani, M.S. (2020) Cement Resources, Agrominerals, Construction, Marble, Dimension and Decor Stone Resources, Gemstone and Jewelry Resources of Pakistan. An update. (In Process)

[24] Malkani, M.S., Mahmood, Z., Somro, N. and Alyani, M.I. (2017) Cement Resources, Agrominerals, Marble, Construction, Dimension and Decorative Stone Resources of Pakistan. Geological Survey of Pakistan, Information Release, 1005, 1-23.

[25] Malkani, M.S., Mahmood, Z., Somro, N. and Arif, S.J. (2017) Gemstone and Jewelry Resources of Pakistan. Geological Survey of Pakistan, Information Release, 1004, $1-28$.

[26] Malkani, M.S., Mahmood, Z., Alyani, M.I. and Siraj, M. (2017) Mineral Resources of Khyber Pakhtunkhwa and FATA, Pakistan. Geological Survey of Pakistan, Information Release, 996, 1-61.

[27] Malkani, M.S., Khosa, M.H., Alyani, M.I., Khan, K., Somro, N., Zafar, T., Arif, J. and Zahid, M.A. (2017) Mineral Deposits of Khyber Pakhtunkhwa and FATA, Pakistan. Lasbela University Journal of Science and Technology, 6, 23-46.

[28] Malkani, M.S. and Mahmood, Z. (2016) Mineral Resources of Azad Kashmir and Hazara (Pakistan): Special Emphasis on Bagnotar-Kala Pani (Abbottabad, Hazara) New Coalfield. Abstract Volume, Earth Sciences Pakistan 2016, 15-17 July, Baragali Summer Campus, University of Peshawar, Pakistan. Journal of Himalayan Earth Sciences, ESP Volume 2016, 103.

[29] Malkani, M.S., Shah, M.R., Sajjad, A., Kakepoto, A.A. and Haroon, Y. (2013) Mineral and Gemstone Resources of Northern Khyber Pakhtunkhwa and FATA Regions, Pakistan-A Good Hope. Abstract Volume, Sustainable Utilization of Natural Resources of the Khyber Pakhtunkhwa and FATA, February 11, Peshawar, Pakistan. Journal of Himalayan Earth Sciences, Special Volume 2013, 25-26.

[30] Malkani, M.S. (2013) Natural Resources of Southern Khyber Pakhtunkhwa and FATA Regions (Kohat Sub-Basin and Part of Northern Sulaiman Basin and Western Indus Suture), Pakistan-A Review. Abstract Volume, Sustainable Utilization of Natural Resources of the Khyber Pakhtunkhwa and FATA, February 11, Peshawar, Pakistan. Journal of Himalayan Earth Sciences, Special volume 2013, 30-31.

[31] Malkani, M.S. (2012) Natural Resources of Khyber Pakhtunkhwa, Gilgit-Baltistan and Azad Kashmir, Pakistan. In: Abstract Volume, Earth Sciences Pakistan 2012, June 23-24, Baragali Summer Campus, University of Peshawar, Pakistan. Journal of 
Himalayan Earth Sciences, 45, 70.

[32] Malkani, M.S., Mahmood, Z., Shaikh, S.I. and Alyani, M.I. (2017) Mineral Resources of North and South Punjab, Pakistan. Geological Survey of Pakistan, Information Release, 995, 1-52.

[33] Malkani, M.S. (2012) A Review on the Mineral and Coal Resources of Northern and Southern Punjab, Pakistan. In: Abstract Volume, Earth Sciences Pakistan 2012, June 23-24, Baragali Summer Campus, University of Peshawar, Pakistan. Journal of Himalayan Earth Sciences, 45, 67.

[34] Malkani, M.S., Mahmood, Z., Alyani, M.I. and Shaikh, S.I. (2017) Mineral Resources of Sindh, Pakistan. Geological Survey of Pakistan, Information Release, 994, $1-38$.

[35] Malkani, M.S. (2014) Mineral Resources of Sindh Province, Pakistan. In: Abstract Volume, Earth Sciences Pakistan 2014, August 29-31, Baragali Summer Campus, University of Peshawar, Pakistan. Journal of Himalayan Earth Sciences, Volume ESP 2014, 57-58.

[36] Malkani, M.S., Mahmood, Z., Usmani, N.A. and Siraj, M. (2017) Mineral Resources of Azad Kashmir and Gilgit Baltistan, Pakistan. Geological Survey of Pakistan, Information Release, 997, 1-40.

[37] Malkani, M.S. (2014) Mineral and Gemstone Resources of Azad Kashmir and Gilgit-Baltistan (Pakistan). In: Abstract Volume, Earth Sciences Pakistan 2014, August 29-31, Baragali Summer Campus, University of Peshawar, Pakistan. Journal of Himalayan Earth Sciences, Volume ESP 2014, 58-59.

[38] Malkani M.S. (2020) Mineral Resources of Gilgit Baltistan and Azad Kashmir, Pakistan: An Update. Open Journal of Geology, 10, 661-702. https://doi.org/10.4236/ojg.2020.106030

[39] Malkani, M.S. and Mahmood, Z. (2016) Revised Stratigraphy of Pakistan. Geological Survey of Pakistan, Record, 127, 1-87.

[40] Malkani, M.S. and Mahmood, Z. (2017) Stratigraphy of Pakistan. Geological Survey of Pakistan, Memoir, 24, 1-134.

[41] Malkani, M.S., Alyani, M.I., Khosa, M.H., Saeed, F., Haroon, A., Buzdar, M.A. and Kakar, A.S. (2015) Revised Stratigraphy of Indus and Balochistan Basins (Pakistan): Sea Level Changes and Land-Ocean Connections of Mesozoic and Cenozoic Strata. Lasbela University Journal of Science and Technology, 4, 21-27.

[42] Malkani, M.S. (2016) Revised Stratigraphy of Indus Basin (Pakistan): Sea Level Changes. In: Dzyuba, O.S., Pestchevitskaya, E.B. and Shurygin, B.N., Eds., Cretaceous Ecosystems and Their Responses to Paleoenvironmental Changes in Asia and the Western Pacific. Short papers for the 4th symposium of IGCP608, 15-20 August 2016, Trofimuk Institute of Petroleum Geology and Geophysics, Siberian Branch, Russian Academy of Science (IPGG SB RAS), Novosibirsk, Russia, 96-99.

[43] Malkani, M.S. (2012) Revised Lithostratigraphy of Sulaiman and Kirthar Basins, Pakistan. In: Abstract Volume, Earth Sciences Pakistan 2012, June 23-24, Baragali Summer Campus, University of Peshawar, Pakistan. Journal of Himalayan Earth Sciences, 45, 72.

[44] Malkani, M.S., Shahzad, A., Umar, M., Munir, H., Sarfraz, Y., Umar, M. and Mehmood, A. (2016) Lithostratigraphy, Structure and Economic Geology of Abbottabad-Nathiagali-Kuldana-Murree Road Section, Abbottabad and Rawalpindi Districts, Khyber Pakhtunkhwa and Punjab Provinces, Pakistan. Abstract Volume, Earth Sciences Pakistan 2016, 15-17 July, Baragali Summer Campus, University of 
Peshawar, Pakistan. Journal of Himalayan Earth Sciences, Volume ESP 2016, 168.

[45] Malkani, M.S. and Mahmood, Z. (2016) Revised Stratigraphy of Uppermost Indus (Khyber-Hazara-Kashmir) Basin, Pakistan. Abstract Volume, Earth Sciences Pakistan 2016, 15-17 July, Baragali Summer Campus, University of Peshawar, Pakistan. Journal of Himalayan Earth Sciences, Volume ESP 2016, 105

[46] Malkani, M.S. (2014) Revised Stratigraphy of Balochistan Basin, Pakistan. In: Abstract Volume, Earth Sciences Pakistan 2014, August 29-31, Baragali Summer Campus, University of Peshawar, Pakistan. Journal of Himalayan Earth Sciences, Volume ESP 2014, 59-60.

[47] Malkani, M.S. (2000) Preliminary Report on Gypsum Deposits of Sulaiman Range, Pak. Geological Survey of Pakistan, Information Release, 706, 1-11.

[48] Malkani, M.S. (2018) Cement Resources and Gypsum Deposits of Pakistan: Urgent Installation of Cement Industries in Daman of Sulaiman Range. In: 5th International Conference on "Earth Sciences Pakistan 2018" August 11-13, 2018, Baragali Campus, University of Peshawar, Pakistan. Journal of Himalayan Earth Sciences, Volume ESP 2018, 180.

[49] Malkani, M.S. (2002) First Note on the Occurrence of Fluorite in Mula Area, Khuzdar District, Balochistan, Pakistan. Geological Survey of Pakistan, Information Release, 766, 1-11.

[50] Malkani, M.S. (2004) Discovery of Fluorite Deposits from Mula-Zahri Range, Khuzdar District, Balochistan, Pakistan. In: Fifth Pakistan Geological Congress, Abstract Volume, Islamabad, Pakistan, 20-22.

[51] Malkani, M.S. (2012) Discovery of Fluorite Deposits from Loralai District, Balochistan, Pakistan. In: Abstract Volume, Earth Sciences Pakistan 2012, June 23-24, Baragali Summer Campus, University of Peshawar, Pakistan. Journal of Himalayan Earth Sciences, 45, 69.

[52] Malkani, M.S. (2015) Mesozoic Tectonics and Sedimentary Mineral Resources of Pakistan. In: Zhang, Y., Wu, S.Z. and Sun, G., Eds., Abstract Volume, 12th Symposium on "Mesozoic Terrestrial Ecosystems (MTE 12), and 3rd Symposium of IGCP 608 "Cretaceous Ecosystem of Asia and Pacific", August 15-20, 2015, Paleontological Museum of Liaoning/Shenyang Normal University, Shenyang, China, 261-266.

[53] Malkani, M.S., Alyani, M.I. and Khosa, M.H. (2016) New Fluorite and Celestite Deposits from Pakistan: Tectonic and Sedimentary Mineral Resources of Indus Basin (Pakistan)-An Overview. Lasbela University Journal of Science and Technology, 5, 27-33.

[54] Malkani, M.S. and Mahmood, Z. (2017) Fluorite from Loralai-Mekhtar and Celestite from Barkhan, Dera Bugti, Kohlu, Loralai and Musakhel districts (Sulaiman Foldbelt) and Karkh Area of Khuzdar District (Kirthar Range): A Glimpse on Tectonic and Sedimentary Mineral Resources of Indus Basin (Pakistan). Geological Survey of Pakistan, Information Release, 981, 1-16.

[55] Malkani, M.S. (2012) Discovery of Celestite Deposits in the Sulaiman (Middle Indus) Basin, Balochistan, Pakistan. Abstract Volume and Program, Earth Sciences Pakistan, Baragali Summer Campus, University of Peshawar, June 23-24, Pakistan. Journal of Himalayan Earth Sciences, 45, 68-69.

[56] Malkani, M.S. (2004) Coal Resources of Chamalang, Bahney Wali and Nosham-Bahlol Areas of Kohlu, Barkhan, Loralai and Musa Khel Districts, Balochistan, Pakistan. In: Abstract Volume, National Conference on Economic and Environmental sustainability of Mineral resources of Pakistan, Baragali, Pakistan, 44-45. 
[57] Malkani, M.S. (2012) A review of Coal and Water resources of Pakistan. Journal of Science, Technology and Development, 31, 202-218.

[58] Malkani, M.S., Alyani, M.I., Khosa, M.H. Buzdar, F.S. and Zahid, M.A. (2016) Coal Resources of Pakistan: New Coalfileds. Lasbela University Journal of Science and Technology, 5, 7-22.

[59] Malkani, M.S. (2016) New Coalfields of Balochistan, Khyber Pakhtunkhwa, FATA and Azad Kashmir. In: Qazi, M.S. and Ali, W., Eds., Abstract Volume, International Conference on Sustainable Utilization of Natural Resources, October 03, National Centre of Excellence in Geology, University of Peshawar, Peshawar, Pakistan. Journal of Himalayan Earth Sciences, Volume ESP 2016, 53-54.

[60] Malkani, M.S. and Mahmood, Z. (2017) Coal Resources of Pakistan: Entry of New Coalfields. Geological Survey of Pakistan, Information Release, 980, 1-28.

[61] Malkani, M.S. (2018) Chamalang-Lunda-Nosham coalfields of Balochistan, Pakistan: Foresight Strategy and Policy. In: 5th International Conference on "Earth Sciences Pakistan 2018” August 11-13, 2018, Baragali Campus, University of Peshawar, Pakistan. Journal of Himalayan Earth Sciences, Volume ESP 2018, 26.

[62] Malkani, M.S. and Dhanotr, M.S.I. (2018) Kingri and Toi Nala (Ghoze Ghar-Savi Ragha) Coalfields of Musakhel District, Balochistan, Pakistan: Foresight Strategy. In: 5th International Conference on "Earth Sciences Pakistan 2018" August 11-13, 2018, Baragali Campus, University of Peshawar, Pakistan. Journal of Himalayan Earth Sciences, Volume ESP 2018, 21.

[63] Malkani, M.S. (2013) Coal and Petroleum Resources of Khyber Pakhtunkhwa and FATA (Pakistan)-An Overview. Abstract, Sustainable Utilization of Natural Resources of the Khyber Pakhtunkhwa and FATA. Abstract Volume, Sustainable Utilization of Natural Resources of the Khyber Pakhtunkhwa and FATA, February 11, Peshawar, Pakistan. Journal of Himalayan Earth Sciences, Special Volume 2013, 27-29.

[64] Malkani, M.S. and Mahmood, Z. (2016) Coal Resources of Pakistan: New Coalfields of Balochistan, Khyber Pakhtunkhwa and Azad Kashmir. Abstract Volume, Earth Sciences Pakistan 2016, 15-17 July, Baragali Summer Campus, University of Peshawar, Pakistan. Journal of Himalayan Earth Sciences, Volume ESP 2016, 102.

[65] Malkani, M.S. and Shah, M.R. (2016) Chamalang Coal Resources and Their Depositional Environments, Balochistan, Pakistan. Geological Survey of Pakistan, Information Release, 969, 1-13.

[66] Malkani, M.S. and Shah, M.R. (2014) Chamalang Coal Resources and Their Depositional Environments, Balochistan, Pakistan. Journal of Himalayan Earth Sciences, 47, 61-72.

[67] Ahmad, W., Gauhar, S.H. and Siddiqui, R.A. (1986) Coal Resources of Pakistan. Geological Survey of Pakistan, Record, 73, 1-55.

[68] Ghaznavi, M.I. (2002) An Overview of Coal Resources of Pakistan. Geological Survey of Pakistan, Pre Publication Issue, 114, 1-167.

[69] Malkani, M.S. and Mahmood, Z. (2016) Clay (Ceramic) Mineral Resources of Pakistan: Recent Advances in Discoveries. In: Earth Sciences Pakistan 2016, 15-17 July, Baragali Summer Campus, University of Peshawar, Pakistan. Journal of Himalayan Earth Sciences, Volume ESP 2016, 101.

[70] Malkani, M.S. and Tariq, M. (2000) Barite Mineralization in Mekhtar Area, Loralai District, Balochistan, Pakistan. Geological Survey of Pakistan, Information Release, 672, 1-9. 
[71] Malkani, M.S. and Tariq, M. (2004) Discovery of Barite Deposits from the Mekhtar Area, Loralai District, Balochistan, Pakistan. In: Abstract Volume, National Conference on Economic and Environmental Sustainability of Mineral Resources of $\mathrm{Pa}$ kistan, Baragali, Pakistan, 48.

[72] Malkani, M.S. (2010) New Pakisaurus (Pakisauridae, Titanosauria, Sauropoda) Remains, and Cretaceous Tertiary (K-T) Boundary from Pakistan. Sindh University Research Journal (Science Series), 42, 39-64.

[73] Malkani, M.S., Qazi, S., Mahmood, Z., Khosa, M.H., Shah, M.R., Pasha, A.R. and Alyani, M.I. (2016) Agromineral Resources of Pakistan: An Urgent Need for Further Sustainable Development. In: Qazi, M.S. and Ali, W., Eds., Abstract Volume, International Conference on Sustainable Utilization of Natural Resources, October 03, National Centre of Excellence in Geology, University of Peshawar, Peshawar, Pakistan. Journal of Himalayan Earth Sciences, Special Volume 2016, 51-52.

[74] Mahmood, Z. and Malkani, M.S. (2017) Good Quality Marble Deposits from Nausehri-Jhugian Area of Muzaffarabad Region, Neelam valley, Azad Kashmir (Pakistan). Geological Survey of Pakistan, Information Release, 978, 1-11.

[75] Malkani, M.S. and Mahmood, Z. (2017) Micaceous Hematite Deposit from Bala Pir-Bela Noor Shah Area of Muzaffarabad District, Azad Kashmir (Pakistan). Geological Survey of Pakistan, Information Release, 977, 1-10.

[76] Malkani, M.S., Qazi, S., Khosa, M.H., Shah, M.R., Zafar, T. and Arif, J. (2018) Iron, Laterite, Bauxite and Ochre Deposits of Pakistan: Emphasis on Feasible Dilband and Low Grade Fort Munro Ironstones. In: 5th International Conference on "Earth Sciences Pakistan 2018" August 11-13, 2018, Baragali Campus, University of Peshawar, Pakistan. Journal of Himalayan Earth Sciences, Volume ESP 2016, 178-179.

[77] Malkani, M.S., Qazi, S., Khosa, M.H., Shah, M.R., Zafar, T. and Arif J. (2018) Industrial Mineral Deposits of Pakistan: Significant for Sustainable Development of Pakistan. In: 5th International Conference on "Earth Sciences Pakistan 2018" August 11-13, 2018, Baragali Campus, University of Peshawar, Pakistan. Journal of Himalayan Earth Sciences, Volume ESP 2018, 175-176.

[78] Malkani, M.S., Qazi, S., Shah, M.R. and Zafar, T. (2018) Sandstone Type Uranium Resources of Pakistan: Encouraging Huge Strata. In: 5th International Conference on "Earth Sciences Pakistan 2018" August 11-13, 2018, Baragali Campus, University of Peshawar, Pakistan. Journal of Himalayan Earth Sciences, Volume ESP 2018, 167.

[79] Aminullah and Kansi, M.A. (2012) Revised Stratigraphy of Nisai Group, Balochistan. Abstract Volume and Program, Earth Sciences Pakistan, Baragali Summer Campus, University of Peshawar, June 23-24, Pakistan. Journal of Himalayan Earth Sciences, Volume ESP 2012, 45.

[80] Malkani, M.S., Dhanotr, M.S.I., Latif, A. and Saeed, H.M. (2013) New Remains of Basilosauridae-The Giant Basal Whale, and Baluchithere-The Giant Rhinoceros Discovered from Balochistan Province (Pakistan). Sindh University Research Journal (Science Series), 45, 177-188.

[81] Malkani, M.S. and Dhanotr, M.S.I. (2014) New Remains of Giant Basilosauridae (Archaeoceti, Cetacea, Mammilia) and Giant Baluchithere (Rhinocerotoidea, Perissodactyla, Mammalia) Found from Pakistan. In Abstract Volume of 1st Symposium of IGCP 632 "Geologic and Biotic Events on the Continent during the Jurassic/Cretaceous Transition" and 4th International Palaeontological Congress, September 28 to October 3, 2014, Mendoza, Argentina, 884. 
[82] Malkani, M.S. (2019) Recently Discovered Basilosaurid, Baluchithere Rhinoceros, Horses, Sea Cow, Proboscidean, Eucrocodile, Pterosaurs, Plesiosaur, Fishes, Invertebrates and Wood Fossils, Tracks and Trackways of Dinosaurs from Pakistan; Comparison of Recognized Four Titanosaur Taxa of Indo-Pakistan with Madagascar. Open Journal of Geology, 9, 919-955. https://doi.org/10.4236/ojg.2019.912098

[83] Malkani, M.S. (2009) New Balochisaurus (Balochisauridae, Titanosauria, Sauropoda) and Vitakridrinda (Theropoda) Remains from Pakistan. Sindh University Research Journal (Science Series), 41, 65-92.

[84] Vredenburg, E. (1901) A Geological Sketch of Balochistan Desert and Part of Eastern Persia. Geological Survey of India, Memoir, 31, 179-302.

[85] Younas, M., Malkani, M.S., Mustafa, G. and Hussain, S.A. (1995) Geology of Warro area $31 \mathrm{M} / 16$, Panjgur and Kharan Districts, Balochistan, Pakistan. Geological Survey of Pakistan, Information Release, 571, 1-19.

[86] Younas, M., Hafeez, M.A., Malkani, M.S. and Hussain, S.A. (1995) Geology of Dastak Area 31 M/12, Kharan and Panjgur Districts, Balochistan, Pakistan. Geological Survey of Pakistan, Information Release, 576, 1-18.

[87] Younas, M., Malkani, M.S., Hussain, S.A. and Mustafa, G. (1995) Geology of Bibi Jan Area 31M/15, Kharan and Panjgur Districts, Balochistan, Pakistan. Geological Survey of Pakistan, Information Release, 579, 1-19.

[88] Younas, M., Hussain, S.A., Qureshi, I.H. and Ahmed, S.A. (1995) Geological Map of 35A/4, Balochistan, Pakistan (unpublished).

[89] Younas, M., Hussain, S.A., Hafeez, M.A. and Malkani, M.S. (1995) Geology of Kalag area 31N/13, Panjgur District, Balochistan, Pakistan. Geological Survey of Pakistan, Information Release, 582, 1-16.

[90] Hussain, S.A., Younas, M., Hafeez, M.A. and Malkani, M.S. (1995) Geology of Turbat area 31N/4, Turbat District, Balochistan, Pakistan. Geological Survey of Pakistan, Information Release, 581, 1-15.

[91] Iqbal, M. and Khan, K. (1995) Geology of Lidi Quadrangle (Toposheet 35A/14), Balochistan. Geological Survey of Pakistan, Map.

[92] Hafeez, M.A., Malkani, M.S., Hussain, S.A. and Younas, M. (1995) Geology of Zurati Area 31 M/11, Kharan District, Balochistan, Pakistan. Geological Survey of Pakistan, Information Release, 578, 1-20.

[93] Mustafa, G., Hussain, S.A., Younas, M. and Malkani, M.S. (1995) Geology of Sabzab area 35A/12, Panjgur and Kharan Districts, Balochistan, Pakistan. Geological Survey of Pakistan, Information Release, 573, 1-18.

[94] Malkani, M.S. and Rana, A.N. (1995) Geology of Jauder Area 35A/11, Kharan District, Balochistan, Pak. Geological Survey of Pakistan, Information Release, 592, $1-22$.

[95] Malkani, M.S., Hussain, S.A., Younas, M. and Hafeez, M.A. (1995) Geology of Panjgur Area 35B/1, Panjgur District, Balochistan, Pakistan. Geological Survey of Pakistan, Information Release, 584, 1-18.

[96] Malkani, M.S., Hussain, S.A., Younas, M. and Hafeez, M.A. (1995) Geology of Wazhdad Area 35A/6, Kharan District, Balochistan. Geological Survey of Pakistan, Information Release, 583, 1-15.

[97] Tariq, M., Malkani, M.S., Qureshi, I.H., Ahmed, S.A. and Muhammad, A. (1998) Geology of Shirinab Area, Kalat District, Balochistan, Pakistan. Geological Survey of Pakistan, Information Release, 543. 
[98] Blanford, W.T. (1879) The Geology of Western Sind. Geological Survey of India, Memoir, 17, pt. 1, 1-196.

[99] Islam, N.U., Hussain, S.A., Abbas, S.Q. and Ashraf, M. (2010) Mineral Statistics of Pakistan. Geological Survey of Pakistan, Special Issue.

[100] LeMessurier, G. (1844) Antimony and Lead Mines of Balochistan. Journal of the Bombay Branch of the Royal Asiatic Society, 2, 1-109.

[101] Klinger, F.L., Matzko, J.J. and Abbas, S.H. (undated) Antimony Deposits of Quetta Pishin District, Quetta Division, West Pakistan. Tech. Letter, Geological Survey of Pakistan, unpublished, $24 \mathrm{p}$.

[102] Siddiqui, R.H. (1996) Magmatic Evolution of Chagai-Raskoh Arc Terrane and Its Implication for Porphyry Copper Mineralization. Geological Survey of Pakistan, Geologica, 2, 87-119.

[103] Siddiqi, R.H. (1984) Petrographic and Ore Microscopic Study of Dasht-e-Kain Porphyry Copper-Molybdenum Prospect, Chagai District, Balochistan, Pakistan. Geological Survey of Pakistan, Information Release, 213, 26 p.

[104] White, M.G. (undated) Copper, Lead, Zinc, Antimony and Arsenic in West Pakistan. Tech. Letter, Geological Survey of Pakistan (unpublished).

[105] Ahmad, W. (1962) Mineral Localities in Chagai-Koh Marani Area, Northern Chagai District. Geological Survey of Pakistan, MIC, 13.

[106] Ahmad, W. (1964) Iron, Copper Deposits of Bandegan, Kimri and Jadino, Raskoh Range, Chagai District, West Pakistan. Geological Survey of Pakistan, Information Release, 16.

[107] Ahmad, W., Khan, S.N. and Schmidt, R.G. (1972) Geology and Copper Mineralization of the Saindak Quadrangle, Chagai District, Pakistan. U.S. Geological Survey, Professional Paper 716-A, 21 p. https://doi.org/10.3133/pp716A

[108] Wolfe, J.A. (1976) Economic Geology of Saindak Porphyry Copper Project, Balochistan. Geological Survey of Pakistan, Record, 33.

[109] Menzies, M.M. and Trenholme, L.S. (1976) Saindak Copper Prospect, Balochistan, Pakistan. Geological Survey of Pakistan, Record, 32.

[110] Saigusa, M. (1977) Report on the Geology and Mineralizations of the Talaruk and Makki Chah Prospects in the Kirtaka Area, Chagai District, Balochistan, Pakistan. ESCAP Advisory Services Report EG/3, 41 p.

[111] Sillitoe, R.H. and Khan, S.N. (1977) Geology of Saindak Porphyry Copper Deposit, Pakistan. Transactions of the Institution of Mining and Metallurgy, 86, 27-42.

[112] Bizenjo, M.Y. (1994) Status and Prospects of Saindak Copper-Gold Project. Round Table Conference on Foreign Investment in Explor. and Mining in Pakistan, Islamabad, $5 \mathrm{p}$.

[113] Razique, A. (2001) Potential of Economic Porphyry Copper-Gold Deposits in Western Chagai Magmatic Belt, Balochistan, Pakistan. Acta Mineralogica Pakistanica.

[114] Ahmad, M.U. (1986) Dasht-e-Kain Porphyry Copper Prospect in Context of the Metallogeny of Chagai Calc-Alkaline Volcano Intrusive Complex, Chagai District, Pakistan. Ph.D. Thesis.

[115] Ali, S.T. (1963) Iron Ore Resources of Pakistan. CENTO Symp. Iron Ore. Isphahan, 55-60.

[116] Asrarullah (1979) Iron Ores of Pakistan. Proceedings of the National Seminar on 
Mineral Resources, Lahore, Pakistan, 116-137.

[117] Asrarullah (1978) Iron Ores of Pakistan. Geological Survey of Pakistan, Information Release, 108.

[118] Hussain, S.M. (1983) Nokundi Iron Ore. In 2nd National Seminar on Develop. Mineral Resources, Peshawar, Pakistan, $12 \mathrm{p}$.

[119] Farooq, H. and Rehman, M.A. (1970) Chilghazi Iron Ore, Chagai District, Balochistan, Pakistan. Geological Survey of Pakistan, Record, 20, 23-56.

[120] Schmidt, R.G. (1968) Exploration Possibilities in the West Chagai District, West Pakistan. Economic Geology, 63, 51-60. https://doi.org/10.2113/gsecongeo.63.1.51

[121] Siddiqi, R.H., Khan, W. and Haq, M. (1986) Petrological and Petrographical Studies of North Central Chagai Belt and Its Tectonic Implications. Acta Mineralogica Pakistanica, 2, 12-23.

[122] Siddiqui, R.H., Khan, M.A., Jan, M.Q. and Brohi, I.H. (2010) Paleocene Tholiitic Volcanism and Oceanic Island Arc Affinities of the Chagai Arc, Balochistan, Pakistan. Sindh University Research Journal (Science Series), 42, 83-98.

[123] Muslim, M. (1973) The Evaluation of Sulphur Deposits of Koh-e-Sulatn, District Chagai (Baluchistan). Geological Survey of Pakistan, Record, 21, 8 p.

[124] Asrarullah (1963) Marble Deposits of West Pakistan. CENTO Symp. Indust. Rocks and Min, 179-188.

[125] Ahmad, W. (1965) Onyx Marble Deposits of Chagai District, Quetta Division, West Pakistan. Geological Survey of Pakistan, Record, 12, pt 2.

[126] Ahmad, M.I. (1943) Lead Ore (Galena) Deposits at Saindak and Zonk. Geological Suvey of Pakistan, open file report.

[127] Grundstoff-Technik (1992) Pakistan’s Mineral Wealth. Grundstoff-Technik GmbH, Essen, 72 p.

[128] Hussain, T. (1970) Exfoliation Test of Vermivulite Deposits of Doki River Area, Western Ras Koh Range, Chagai District, Quetta Division, Pakistan. Geological Survey of Pakistan, Information Release, $35 \mathrm{p}$.

[129] Bakar, M.A. (1957) Preliminar Report on Vermiculite near Doki River in West Ras Koh Range, Kalat, Pakistan. Geological Survey of Pakistan, Information Release, 5.

[130] Shcheglov, A.D. (1969) Main Feature of Endogenous Metallogeny of the Southern Part of West Pakistan. Geological Survey of Pakistan, Memoir, 7, 12 p.

[131] Sillitoe, R.H. (1975) Metallogenic Evolution of a Collisional Mountain Belt in Pakistan. Geological Survey of Pakista, Record, 34, 16 p.

[132] Nagell, R.H. (1969) Sulphur, Fluorspar, Magnesite and Aluminous Chromite Deposits in West Pak. U. S. Geological Survey, pk-49, 33 p.

[133] Ahmad, Z. and Abbas, S.G. (1979) The Muslimbagh Ophiolites. In Farah and Dejong, Eds., Geodynamics of Pakistan, Publication of Geological Survey of Pakistan, Special Publication, 243-249.

[134] Asrarullah (1961) Chromite and Mining in Pakistan. Geog. Rec, 16, 1-13.

[135] Bilgrami, S.A. (1956) Mineralogy and Petrology of Muslimbagh Igneous Complex. Ph.D. Thesis, University of Manchester, UK.

[136] Bilgrami, S.A. (1961) Distribution of Cu, Ni, Co, V, and Cr in Rocks of the Hindubagh Igneous Complex, Zhob Valley, West Pakistan. GSA Bulletin, 72, 1729-1738. https://doi.org/10.1130/0016-7606(1961)72[1729:DOCNCV]2.0.CO;2

[137] Rossman, D.L. and Abbas, S.G. (1970) Geology and Economic Potential for Chro- 
mite in the Zhob Valley Ultramafic Complex (Jang Tor Ghar) Hindubagh, Quetta/Division, West Pakistan. Geological Survey of Pakistan and U.S. Geological Survey, Interim Report, Open-File Report 71-242, 63 p.

https://doi.org/10.3133/ofr71242

[138] Dejong, K.A. and Subhani, A.M. (1979) Notes on Bela Ophiolites with Special Reference to the Kanar Area. In: Farah, A. and Dejong, K.A. (Eds.), Geodynamics of Pakistan. GSP Geological Survey of Pakistan, Quetta, Pakistan, 263-269.

[139] Ahsan, S.N. and Qureshi, A.H. (1997) Mineral/Rock Resources of Lasbela and Khuzdar Districts, Balochistan, Pakistan. Geol. Bull. Peshawar, 30, 41-52.

[140] Van Vloten, R. (1963) Magnesite in Pakistan. In Symp. Lahore, 211-215.

[141] Bashir, E. (2008) Geology and Geochemistry of Magnesite ore Deposits of Khuzdar Area. Ph.D. Thesis, Department of Geology, University of Karachi, Karachi, 391 p.

[142] Ahmad, M.I. and Klinger, F.L. (1967) Barite Deposits near Khuzdar. Pak-Series Report 21. Geological Survey of Pakistan and U.S. Geological Survey, publication.

[143] Jankovic, S. (1984) Mineral Association and Genesis of Lead Zinc Barite Deposits at Gunga, Khuzdar, Balochistan. Geological Survey of Pakistan, Record, 71, 12 p.

[144] Azam, S., Qureshi, J.M., Khan, M.Z., Tariq, M.A., Akhtar, J.M. and Khanzada, M.I. (1989) Preliminary Geoeconomic Evaluation of Duddar Area Zinc-Lead and Barite Deposits, Lasbela District, Balochistan, Pakistan. Geological Survey of Pakistan, Information Release, 447, 1-44.

[145] Jones, G.V. and Shah, S.H. (1994) Present Status and Potential of Duddar Zinc-Lead Deposit. Round Table Conference on Foreign Investment in Exploration and Mining in Pakistan, Pakistan, 16-18 October 1994, 18 p.

[146] Ahsan, S.N and Khan, K.S.A. (1994) Pakistan Mineral Prospects: Lead and Zinc. Round Table Conference on Foreign Investment in Exploration and Mining in Pakistan, Pakistan, 16-18 October 1994, 10 p.

[147] Nakagawa, M., Siddiqui, R.H. and Hoshino, K. (1996) Prelim Assess on Ultrmafics Related Mineralization of Muslim Bagh Ophiolites. Geological Survey of Pakistan, Proc. Geosc. Colloquium, 16, 195-212.

[148] Page, N.J., Haffty, J. and Ahmad, Z. (1979) Platinum, Palladium and Rhodium Concentrations in Mafic and Ultramafic Rocks from the Zhob Valley and Dargai Complex, Pakistan. U.S. Geological Survey, Professional Paper, 1124, 1-6.

[149] Subhani, A.M. and Durezai, M.I. (1989) A Note on the Surmai Lead-Zinc Prospect, District Khuzdar, Balochistan. Geological Survey of Pakistan, unpublished report.

[150] Rizvi, S.M.N. (1951) Manganese Deposits of Lasbela. Geological Survey of Pakistan, open file, $16 \mathrm{p}$.

[151] Nasim, S. (1996) The Genesis of Manganese Ore Deposits of Las Bela, Balochistan, Pakistan. Ph.D. Thesis, Geology Department, Karachi University, Karachi, 262 p.

[152] Master, J.M., Rizvi, S.M.N. and Shah, S.H.A. (1952) A Note on Manganese Ore in Lasbela. Geological Survey of Pakistan, Open File, 541, 4 p.

[153] Naeem, A., Mahmood, K. and Kakar, M.I. (2014) A Study of the Gemstones from the Muslimbagh Ophiolite Complex, Balochistan, Pakistan. In: Abstract Volume, Earth Sciences Pakistan 2014, August 29-31, Baragali Summer Campus, University of Peshawar, Pakistan. Journal of Himalayan Earth Sciences, Volume ESP 2014, 63-64.

[154] Ahmad, W. and Subhani, A.K. (1979) Interim Report on Cupriferous Gossan at Saap Dhora near Uthal in Lasbela District, Balochistan. Geological Survey of Pakis- 
tan, Information Release, 107.

[155] Abbas, S.G. (1980) Kharrari Nai; Bhampani Dhoro and Porar Dhoro Manganese deposits, Lasbela. Geological Survey of Pakistan, Information Release, 122.

[156] Tipper, G.H. (1909) Minerals from Balochistan. Geological Survey of Pakistan, Record, 38, 214-215.

[157] Fatmi, A.N. (1977) Mesozoic. In: Shah, S.M.I., Ed., Stratigraphy of Pakistan, Geological Survey of Pakistan, Memoir, 12, 29-56.

[158] Cheema, M.R. Raza, S.M. and Ahmad, H. (1977) Cainozoic. In: Shah, S.M.I., Ed., Stratigraphy of Pakistan, Geological Survey of Pakistan, Information Release, Geological Survey of Pakistan, Memoir, 12, 56-98.

[159] Raza, H.A. and Iqbal, M.W.I. (1977) Mineral Deposits. In Shah, S.M.I., Ed., Stratigraphy of Pakistan, Geological Survey of Pakistan, Memoir, 12, 98-120.

[160] Ali, S.T. (1978) Mineral Resources of Pakistan. Geological Survey of Pakistan, Information Release, 105.

[161] Ahmad, W. (1981) Metallogenic Framework and Mineral Resources of Pakistan. Chika Shigen Chosago Hokoku, Hokkaido, Japan, 261, 47-76.

[162] Griffiths, J.B. (1987) Pakistan Mineral Potential: Prince or Pauper. Industrial Mineral, 238, 220-243.

[163] Ahmad, W., Durrazai, M.I., Jalil, A. and Azam, S. (1992) Economic Mineral Lead-Zinc-Barite Deposits of Gunga Valley, Khuzdar district. Geological Survey of Pakistan, Record, 79.

[164] Ahsan, S.N. and Bhutta A.M. (1991) Geology and Mineralogy of the Lead-Zinc-Barite Prospects, Lasbela District, Balochistan. Geological Survey of Pakistan, Record, 87.

[165] Ahmad, M. (1965) Marble in Pakistan. Geological Survey of Pakistan, Record, 17.

[166] Sondhi, V.P. (1947) The Makran Earthquake, 28th November 1945; the Birth of New Islands. Indian Minerals, 1, 147-154.

[167] Stiffe, A.W. (1873) On the Mud Craters and Geological Structures of the Makran Coast. The Quarterly Journal of the Geological Society of London, 30, 50-53.

[168] White, R.S. (1979) Deformation of Makran Continental Margin. In: Farah and Dejong, Eds., Geodynamics of Pakistan. Geological Survey of Pakistan, Quetta, 195-304.

[169] Malkani, M.S. (2020) Pakisaurus balochistani (Poripuchia, Slender Titanosauria, Sauropoda) Associated Skeletons Found from the Latest Maastrichtian Vitakri Formation of Pakistan and Referred Fossils from India; Filling of Important Missing Links of Isisaurus colberti Titanosaur Found from Pakistan. Open Journal of Geology, 10, 408-447. https://doi.org/10.4236/ojg.2020.104019

[170] Malkani, M.S. (2020) First Skull of Medium Sized Titanosaur in Indo-Pakistan Subcontinent Found from the Latest Maastrichtian Vitakri Formation of Pakistan; Associated Cranial and Postcranial Skeletons of Gspsaurus pakistani (Poripuchia, Stocky Titanosauria, Sauropoda) from Pakistan and India. Open Journal of Geology, 10, 448-489. https://doi.org/10.4236/ojg.2020.104020

[171] Malkani, M.S. (2020) First Snout with Complete Teeth Row of Small Titanosaur in Indo-Pakistan Found from the Latest Maastrichtian Vitakri Formation of Pakistan; Associated Cranial and Postcranial Skeletons of Saraikimasoom vitakri (Poripuchia, Stocky Titanosauria, Sauropoda) from Pakistan and Referred Fossils from India. Open Journal of Geology, 10, 368-407. https://doi.org/10.4236/ojg.2020.104018

[172] Malkani, M.S. (2006) Biodiversity of Saurischian Dinosaurs from the Latest Creta- 
ceous Park of Pakistan. Journal of Applied and Emerging Sciences, 1, 108-140.

[173] Malkani, M.S. (2020) Theropods, Mesoeucrocodiles and Pterosaurs Found from the Latest Maastrichtian Vitakri Formation of Balochistan, Pakistan; Description with Large Photographs and Comparison with Coeval Taxa from Indo-Pakistan Subcontinent. Open Journal of Geology, 10, 510-551.

https://doi.org/10.4236/ojg.2020.105023

[174] Malkani, M.S. (2007) Trackways Evidence of Sauropod Dinosaurs Confronted by a Theropod Found from Middle Jurassic Samana Suk Limestone of Pakistan. Sindh University Research Journal (Science Series), 39, 1-14.

[175] Malkani, M.S. (2008) Marisaurus (Balochisauridae, Titanosauria) Remains from the Latest Cretaceous of Pakistan. Sindh University Research Journal (Science Series), 40, 55-78. 